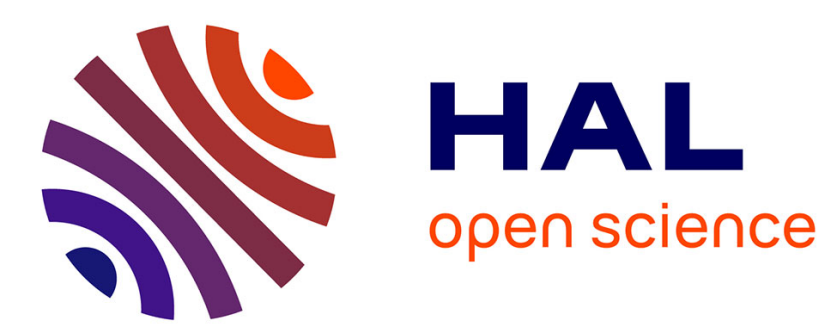

\title{
Metal sources to the Baltic clam (Mollusca: Bivalvia) in the southern Baltic Sea (the Gulf of Gdansk)
}

Adam Sokolowski, Maciej Wolowicz, Herman Hummel

\section{To cite this version:}

Adam Sokolowski, Maciej Wolowicz, Herman Hummel. Metal sources to the Baltic clam (Mollusca: Bivalvia) in the southern Baltic Sea (the Gulf of Gdansk). Marine Environmental Research, 2007, 63 (3), pp.236. 10.1016/j.marenvres.2006.09.001 . hal-00501889

\section{HAL Id: hal-00501889 https://hal.science/hal-00501889}

Submitted on 13 Jul 2010

HAL is a multi-disciplinary open access archive for the deposit and dissemination of scientific research documents, whether they are published or not. The documents may come from teaching and research institutions in France or abroad, or from public or private research centers.
L'archive ouverte pluridisciplinaire HAL, est destinée au dépôt et à la diffusion de documents scientifiques de niveau recherche, publiés ou non, émanant des établissements d'enseignement et de recherche français ou étrangers, des laboratoires publics ou privés. 


\section{Accepted Manuscript}

Metal sources to the Baltic clam Macoma balthica (Mollusca: Bivalvia) in the southern Baltic Sea (the Gulf of Gdansk)

Adam Sokolowski, Maciej Wolowicz, Herman Hummel

PII:

S0141-1136(06)00187-5

DOI:

10.1016/j.marenvres.2006.09.001

Reference:

MERE 3068

To appear in:

Marine Environmental Research

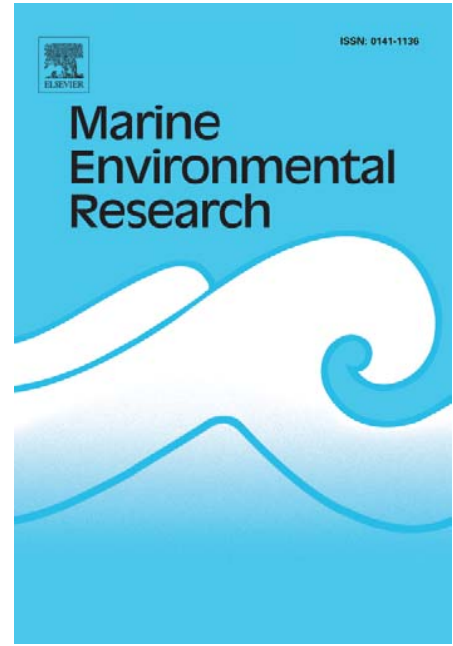

Received Date: $\quad 1$ July 2005

Revised Date: $\quad 24$ August 2006

Accepted Date: $\quad 22$ September 2006

Please cite this article as: Sokolowski, A., Wolowicz, M., Hummel, H., Metal sources to the Baltic clam Macoma balthica (Mollusca: Bivalvia) in the southern Baltic Sea (the Gulf of Gdansk), Marine Environmental Research (2006), doi: 10.1016/j.marenvres.2006.09.001

This is a PDF file of an unedited manuscript that has been accepted for publication. As a service to our customers we are providing this early version of the manuscript. The manuscript will undergo copyediting, typesetting, and review of the resulting proof before it is published in its final form. Please note that during the production process errors may be discovered which could affect the content, and all legal disclaimers that apply to the journal pertain. 
Sokolowski et al. Metal sources to the Baltic clam Macoma balthica in southern Baltic Sea

Metal sources to the Baltic clam Macoma balthica (Mollusca: Bivalvia) in the southern Baltic Sea (the Gulf of Gdansk).

Adam Sokolowski $^{\text {a* }}$, Maciej Wolowicz ${ }^{a}$, Herman Hummel ${ }^{b}$

${ }^{a}$ Laboratory of Estuarine Ecology, Institute of Oceanography, University of Gdansk, Al. M. Pilsudskiego 46, 81-378 Gdynia, Poland

${ }^{\mathrm{b}}$ Centre for Estuarine and Marine Ecology, Netherlands Institute of Ecology, Korringaweg 7, 4401 NT Yerseke, The Netherlands

* Author for correspondence:
tel.: + 48586601640
fax: + 48586202165

E-mail address: oceas@univ.gda.pl 
Sokolowski et al. Metal sources to the Baltic clam Macoma balthica in southern Baltic Sea

\section{Abstract}

2

3 Metal concentrations of $\mathrm{Cu}, \mathrm{Fe}, \mathrm{Mn}, \mathrm{Ni}, \mathrm{Pb}$ and $\mathrm{Zn}$ in an infaunal facultative deposit-feeding bivalve, the Baltic clam Macoma balthica, in the Gulf of Gdansk (southern Baltic Sea) were

5 assessed and compared to selected concentrations of metals in the environment. Between

6 October 1996 and September 1997, dissolved and easy extractable (by $1 \mathrm{M} \mathrm{HCl}$ ) metal

7 fractions of total suspended particulate matter (TPM) in the overlying water and of surficial

8 sediments $(<63 \mu \mathrm{m})$ were measured monthly at five sublittoral sites in the Gulf of Gdansk,

9 and accumulated tissue metal concentrations in $M$. balthica were determined simultaneously.

10 The study highlights the importance of sediment geochemistry as a factor modifying ambient 11 trace metal bioavailabilities. Surficial sediments appeared to contribute most to the 12 accumulation of $\mathrm{Cu}$ and $\mathrm{Pb}$ in Macoma balthica, reflecting the high metal availability in the 13 Gulf. Assimilation of $\mathrm{Cu}$ from sediments is controlled by Mn components possibly through an inhibitory effect of Mn oxyhydroxides, while $\mathrm{Pb}$ accumulation from sediments depends on the

Keywords: metal source; Macoma balthica; surficial sediments; overlying water; Baltic Sea 
Sokolowski et al. Metal sources to the Baltic clam Macoma balthica in southern Baltic Sea

\section{Introduction}

Marine animals can take up metals from solution and the diet which may, for example, consist of particles in suspension or deposited in the sediment. The direct uptake of dissolved metals takes place through passive facilitated diffusion of metal ions or via channels (and pumps) for major ions (for example calcium channels in the case of cadmium) over the permeable external body surface (Simkiss \& Taylor, 1989). The soluble fraction is commonly considered the most bioavailable form of trace metals in the marine environment irrespective of feeding strategy, life history of an individual and geographical region, although Wang (2002) has highlighted that the diet can represent the major route of trace metal uptake. The uptake and subsequent accumulation of elements from particles involves the ingestion of suspended material by suspension feeders such as bivalves, and deposited organic material by sediment dwellers such as polychaetes (Wang \& Fisher, 1999). For these groups suspended and deposited material may thus constitute a considerable source of metals, particularly at organically rich sites. The bioavailability of soluble and particulatebound metals is dependent upon a complex of geochemical factors including the strength of metal-substrate binding, the composition of particles, the abundance of other elements and compounds, potentially affecting metal speciation (Blackmore \& Wang, 2002). A number of studies has addressed the bioavailability of metals from particles by marine benthic invertebrates. It has been shown that availability of $\mathrm{Cd}$ to the deposit feeding sipunculid Sipunculus nudus, for instance, is partially controlled by the amount of organic carbon in sediments (Wang, Yan, Fan, \& Xu, 2002). The enhancing effect of an easily reducible Mn phase was shown to be important in dietary inputs of $\mathrm{Cu}, \mathrm{Cd}, \mathrm{Zn}$ and $\mathrm{Pb}$ from surficial sediments to Macoma balthica (Thomas \& Bendell-Young, 1998), while the oxygen conditions are well known to mediate relative mobility and bioavailability of $\mathrm{Pb}$ and $\mathrm{Zn}$ (Shine, Ika, \& Ford, 1998; Chong \& Wang, 2000).

The efficacy of metal uptake and accumulation can vary also due to factors related to the biology and ecology of animals studied such as feeding behaviour, nature of the diet, size, age and physiology (Rainbow, 1995, 2002). One approach that throws light on the effects of 
Sokolowski et al. Metal sources to the Baltic clam Macoma balthica in southern Baltic Sea

such factors on the kinetics of metal uptake and accumulation is a survey of seasonal variations of the soft tissue body weight, providing information on the physiological condition of an individual (Rainbow \& Philips, 1993). Furthermore, it has been proposed that the feeding and digestion strategy may change in feedback response to temporary fluctuations in environmental metal concentrations. Decho and Luoma (1996) showed that two clam species Macoma balthica and Potamocorbula amurensis are capable of modifying the digestive processing of food to reduce exposure to high ambient biologically available $\mathrm{Cr}$ concentrations.

Although the overall mechanisms for uptake of elements by various benthic molluscs with respect to environmental conditions have been established in several regions (Rainbow, 1996; Maurer, Gerlinger, Robertson, \& Nguyen, 1997), spatial heterogeneity with regard to hydro-geochemical conditions and ecological factors precluded generalisation of metal uptake and accumulation mechanisms. Patterns of metal uptake routes and subsequent accumulation can vary interspecifically for the same metal and intraspecifically for different metals (Rainbow, Philips, \& Depledge, 1990). Site-specific studies are therefore required to clarify unequivocally metal uptake sources in the area of interest, as it is inevitable that local differences in habitat will affect tissue accumulated metal concentrations. This study has set out to investigate metal uptake sources to the Baltic clam M. balthica in the Gulf of Gdansk (southern Baltic Sea), distinguished from other marine basins by low salinity and comparatively high pollution level (Sokolowski, Wolowicz, \& Hummel, 2001; Szefer, 2002).

\section{Materials and Methods}

\subsection{Sampling}

Samples of overlying water, sediments and the Baltic clams $M$. balthica were collected at monthly intervals from October 1996 to September 1997 at five sublittoral sites to depths of 10 m ("SW10"), 20 m ("SW20"), 30 m ("SW30"), 40 m ("SW40") and 60 m ("SW60") in the Vistula River plume, the Gulf of Gdansk (Fig. 1). 
Sokolowski et al. Metal sources to the Baltic clam Macoma balthica in southern Baltic Sea

Overlying water was sampled in triplicate with a Teflon GoFlo modified water sampler (5 I) equipped with metal-free end stoppers and Teflon sealed valves. The sampler was fitted on stainless-steel and polyethylene-coated rope with a polypropylene-coated counterweight at the end, and was used always on the windward site of the vessel. Modification was designed in order to sample water at a constant distance of $20 \mathrm{~cm}$ over the bottom surface and to prevent entrance of particles that were resuspended from the sediment due to usage of the sampler. The samples were pressure filtered with acid-scrubbed $N_{2}$ through $0.45 \mu \mathrm{m}$ precleaned cellulose-nitrate filters under an on-board clean box. Following filtration, water samples were acidified with concentrated $\mathrm{HCl}$ to a final $\mathrm{pH} 1.8$ and stored in dense polyethylene bags at room temperature. The filters containing the retained particulate matter were sucked dry and stored individually in acid-cleaned polystyrene Petri dishes at $-20^{\circ} \mathrm{C}$. A second series of water samples was collected at the same sites and on the same occasions and filtered on a standard filtration system for the determination of total particulate matter (TPM) content.

Samples of the top $5 \mathrm{~cm}$ of sediment were collected in triplicate with a polypropylene sediment corer of $20 \mathrm{~cm}$ length and $2 \mathrm{~cm}$ diameter. This layer represents the fraction of the sediments that $M$. balthica can penetrate and is the biological relevant portion of the sediment. According to Zwarts and Wanink (1989) in a sandy and muddy substrate an optimal burrowing depth of the clam, > $10 \mathrm{~mm}$ long, ranges from $20 \mathrm{~mm}$ in summer to $50 \mathrm{~mm}$ in winter. After sampling, sediments were stored in dense polyethylene bags at $-20^{\circ} \mathrm{C}$ until the time of analysis. Additional sediment samples were collected according to the same procedure for the determination of the fine-grained fraction $(<63 \mu \mathrm{m})$ and its organic component.

The clams were sampled by dredging and transported immediately to the laboratory where they were kept in GF/F (glass microfibre filter; $1.6 \mu \mathrm{m}$ ) filtered sea water at a temperature (3.5 to $19.6^{\circ} \mathrm{C}$ ) and salinity ( 7.1 to 8.6 ) corresponding to the ambient environmental situation for $24 \mathrm{~h}$ to purge gut contents. Special care was taken to select individuals of a restricted size range (11.4-15.0 $\mathrm{mm}$ that refers to individuals of $3-4$ years old) as size has been 
Sokolowski et al. Metal sources to the Baltic clam Macoma balthica in southern Baltic Sea

demonstrated to sometimes affect accumulated soft tissue metal concentrations in bivalves (Wallace, Lee, \& Luoma, 2003). Three pools of 20 individuals each were then prepared to obtain mean metal concentration in each month, and animals were frozen at $-20^{\circ} \mathrm{C}$.

\subsection{Analysis}

Dissolved $\mathrm{Cu}, \mathrm{Pb}$ and $\mathrm{Zn}$ concentrations were measured by differential pulse anodic stripping voltametry (DPASV) and the dissolved Ni concentration was determined by differential pulse cathodic stripping voltametry (DPCSV) after exposure to UV irradiance in the presence of $\mathrm{H}_{2} \mathrm{O}_{2}$ (25 ml of sample $+0.01 \mathrm{ml}$ of $\mathrm{H}_{2} \mathrm{O}_{2}$ ) for $4 \mathrm{~h}$ to destroy dissolved organic ligands. Measurements were carried out up to one month after collection in a laminar flow bench. Manganese and Fe were measured directly on sea water samples with a graphite furnace atomic absorption spectrometer (GF-AAS). Quality assurance and quality control was maintained through inclusion of the estuarine water certified reference material (SLEW-2) from NRC-INMS, Canada, and reagent blanks. Recovery and precision (calculated on the basis of coefficients of variation) varied between metals and were $90-121 \%$ and $<12 \%$, respectively.

The extraction technique used to leach the particulate matter was that given by Luoma and Bryan (1981). This method determines the fraction of elements in the particulates associated with Fe- and Mn-oxides and by this estimates the relatively labile and potentially bioavailable phase of the metal (Bryan \& Langston, 1992). Filters with the retained suspended material were extracted with $5 \mathrm{ml} 1 \mathrm{M} \mathrm{HCl}$ for $2 \mathrm{~h}$ at room temperature, and shaken occasionally. The final extracts were analysed by GF-AAS. Analysis of the estuarine sediment standard reference material (BCR-277) from NRC-INMS was systematically performed using Aqua Regia solution $\left(\mathrm{HNO}_{3} / \mathrm{HCl} / \mathrm{H}_{2} \mathrm{O}=9: 3: 10 \mathrm{v} / \mathrm{v} / \mathrm{v}\right)$ in a Microwave Digestion System (MDS-200, CEM) to control the quality of the results. Recovery $(81-103 \%)$ and precision $(<16 \%)$ were considered satisfactory. A detailed description of the procedures used to clean field and laboratory materials, analytical methods for dissolved and particulate metals, and the results of the quality control tests is in Sokolowski, Wolowicz, \& Hummel (2001). Total particulate 
Sokolowski et al. Metal sources to the Baltic clam Macoma balthica in southern Baltic Sea

matter content (TPM) was determined according to standard methods recommended for the Baltic Sea (Kramer, Brockman, \& Warwick, 1994).

Prior to trace metal analyses, sediments were air-dried at $55^{\circ} \mathrm{C}$ to constant weight and dry sieved through a $63 \mu \mathrm{m}$ mesh to obtain the fine-grained fraction. Separation of the $<63 \mu \mathrm{m}$ fraction is a commonly used standardised procedure to compensate for grain size effects on metal variability in sediments (Szefer, Glasby, Pempkowiak, \& Kaliszan, 1995). The residue retained after sieving was separated into two subsamples. One subsample was subjected to extraction with $1 \mathrm{M} \mathrm{HCl}$ according to the same method as used for TPM, with a modification in the final part of the procedure. After extraction, the extraction mixture (sediments $+1 \mathrm{M} \mathrm{HCl}$ ) was centrifuged in glass acid-precleaned test tubes at $3000-3500 \mathrm{rpm}$ and $10^{\circ} \mathrm{C}$ for $10 \mathrm{~min}$. to separate sediment particles from the solution, and the aliquot was pipetted off. Samples were then made up to a volume of $10 \mathrm{ml}$ and metal concentrations were determined by a flame atomic absorption spectrometer (F-AAS). The second subsample of the $<63 \mu \mathrm{m}$ sediment fraction was subjected to ignition at $500^{\circ} \mathrm{C}$ for $8 \mathrm{~h}$ in order to determine organic matter content.

When required for analysis, the clams were thawed, cleaned of debris and dissected using Teflon or polypropylene instruments. The whole soft tissue was freeze-dried, homogenised and $300 \mathrm{mg}$ of aliquot was digested with $5 \mathrm{ml} 14 \mathrm{~N} \mathrm{HNO}_{3}$ in a Microwave Digestion System (MDS-200, CEM). The solution remaining after digestion was made up to $5 \mathrm{ml}$ and measured for metal concentrations in F-AAS. Quality control for sediments and clams was provided by concurrent checks of the estuarine sediment (MESS-2) and lobster hepatopancreas reference materials (TORT-1) from NRC-INMS, respectively and analytical blanks that were analysed according to the same procedures. The results for recovery and precision met acceptance criteria (Table 1).

\subsection{Statistical analysis}

Untransformed data were included in all statistical models followed by analysis of normality (the Kolmogorov-Smirnov test for goodness of fit) and homogeneity of variances as 
Sokolowski et al. Metal sources to the Baltic clam Macoma balthica in southern Baltic Sea

prerequisites to the parametric approach. The significance of the influence of month and site on metal concentrations in the environment and clams was evaluated by analysis of variance (two-way ANOVA) and functional relationships between pairs of variables (i.e. dissolved, particulate-bound and sediment metal concentrations vs. metal concentrations in the clam) were assessed with regression analysis. For particulate-bound metals, analyses were performed separately for the concentration ( $\mu \mathrm{g}$ dry $\mathrm{wt}^{-1}$ ) and the content of elements expressed per unit of water volume $\left(\mu \mathrm{g} \mathrm{I}^{-1}\right)$ to calculate the concentration of suspended fraction in the water column. The level of significance for all tests was set as $p<0.05$ (Sokal \& Rohlf, 1995). Statistical analyses were carried out using STATISTICA for Windows (StatSoft, Inc., 1997).

\section{Results}

\subsection{Total Particulate Material (TPM) and sediment parameters}

Spatial and temporal variations in TMP in the overlying water in the Vistula River plume are described in Sokolowski, Wolowicz, \& Hummel (2001). Briefly, high concentrations of TPM were recorded near-shore due to riverine outflow, with a trend to decrease with depth and distance from the river mouth. Elevated concentrations of TPM occurred in spring and late summer/early autumn, particularly at the shallow sites SW10 and SW20, and were attributed to intense primary production and algal blooms in the water column enhanced by increased temperature in this season and eutrophication of the river. The percentage contribution of the $<63 \mu \mathrm{m}$ fraction in surficial sediments and the contribution of organic components in the fraction showed strong spatial differences but no clear seasonal trends were apparent (Table 2). The highest contribution $(69.4 \%)$ of the $<63 \mu \mathrm{m}$ fraction was at the deepest site SW60 which lies below the thermo-halocline and furthest off-shore. This fraction was also relatively rich in organic matter (average $7.1 \%$ ). In the area adjacent to the river mouth, the fine-grained fraction constituted on average $21.6-23.1 \%$ of the sediments and decreased to $6.1-6.7 \%$ in the mid-deep part of the plume (SW30 and SW40). In contrast, the contribution 
Sokolowski et al. Metal sources to the Baltic clam Macoma balthica in southern Baltic Sea

of organic components in the fraction at SW10 and SW20 ranged from 9.4 to $9.7 \%$, while at SW30 and SW40 it varied between 6.1 and $6.7 \%$. Such a distribution pattern reflects the overall scheme of sorting and sedimentation processes of suspended matter and is typical for the estuarine areas and the regions adjacent to the mouths of big rivers.

3.2. Concentrations of dissolved and easily extractable fractions of particulate- and sedimentbound metals

Spatial and temporal variability of metal concentrations in different compartments of the environment within the plume was high (Table 3 and Fig. 2-5). All dissolved metals, except Mn, showed minima in the mid-deep zone of the plume (SW30) and maxima in shallow(SW10 and SW20) and deep-water parts (SW40 and SW60), most pronounced for Pb (Fig. 2). Dissolved Mn showed the highest concentrations near-shore with a tendency to decrease gradually with depth and the distance from the Vistula River mouth. Particulate-bound $\mathrm{Cu}$, $\mathrm{Fe}, \mathrm{Mn}$ and Ni demonstrated similar distribution profiles with lowered concentrations at SW30 $(\mathrm{Cu})$ and SW40 (Fe, Mn, Ni) and an increase towards the coast and towards the more open part of the Gulf (Fig. 3). In contrast, highest concentrations of particulate-bound $\mathrm{Pb}$ and $\mathrm{Zn}$ were found in the deep zone (SW60) to decrease adjacent to the river mouth (SW10). For most particulate metals lowest concentrations were recorded in May and highest concentrations in June and July, except $\mathrm{Pb}$ whose lowest level occurred mainly in May (Fig. 3-4). A strong effect of site on metal concentrations was also apparent for surficial sediments (Table 3) but no consistent seasonal trends were observed (Fig. 5). The concentrations of $\mathrm{Cu}, \mathrm{Fe}, \mathrm{Ni}, \mathrm{Pb}$ and $\mathrm{Zn}$ in the fine-grained fraction of sediments increased from the shallow site SW10 up to a maximum at SW20 followed by a slight decrease towards SW40 (Cu, Fe, $\mathrm{Pb}, \mathrm{Zn}$ ) and the deep zone (SW60, Ni). The distribution profile for Mn was distinct from other metals, highest concentrations of $\mathrm{Mn}$ being found near-shore with a decrease towards an open part of the Gulf.

\subsection{Metal concentrations in clams}


Sokolowski et al. Metal sources to the Baltic clam Macoma balthica in southern Baltic Sea

Accumulated soft tissue metal concentrations in the clam varied between sites and seasons (Table 3). Copper, Fe and Zn exhibited parallel distribution profiles along the transect studied with elevated concentrations in the mid-deep part of the plume and a marked tendency to decrease seawards and landwards (Fig. 6), a reverse pattern being demonstrated for Ni. The concentration of Fe increased slightly from the shallow-water to the deep-water zone and towards an open part of the Gulf while concentrations of Mn showed maxima adjacent to the river mouth and a decrease in the deep-water zone. The pattern for $\mathrm{Pb}$ was intermediate.

Accumulated metal concentrations of $M$. balthica varied significantly with season among metals and in some cases also with sites, suggesting different accumulation patterns for each element. Elevated levels of $\mathrm{Cu}, \mathrm{Pb}$ and $\mathrm{Zn}$ were noticed during autumn and winter (September through February) to diminish in spring and summer (March through August), the pattern being most pronounced for $\mathrm{Pb}$. The tissue concentration of $\mathrm{Cu}$ in the shallow-water zone remained fairly stable throughout much of the year with only minor variations. High concentrations of Mn were recorded in autumn (September and October) and spring (March through May) and low concentrations occurred in winter, particularly at a depth of $10-30 \mathrm{~m}$. The concentration of $\mathrm{Fe}$ in $M$. balthica increased in spring (March and April) at all sites, except SW60 where the maximum was observed already in February, followed by a sharp decrease in summer and autumn (July through September). No distinct seasonal cycle was evident for $\mathrm{Ni}$.

\subsection{Extractable metals vs. metals accumulated in Macoma balthica}

Relationships between (extractable) metal concentrations in different components of the environment and metal concentrations in the Baltic clam were determined, using the correlation coefficient at the confidence level of $95 \%$, to assess potential metal sources to the bivalve. Since the liability of metals and thus their potential bioavailability from sediments is dependent on various sediment components, mathematical normalisation for the effects of concentrations of labile forms of Fe and $\mathrm{Mn}$, the percentage contribution of $<63 \mu \mathrm{m}$ fraction and its organic component in surficial sediments was additionally employed to model the 
Sokolowski et al. Metal sources to the Baltic clam Macoma balthica in southern Baltic Sea

bioavailability of sediment-bound metals. The normalisation procedure was performed individually on each metal by dividing metal concentration by a respective factor. Surficial sediments and TPM appear to be the main sources of metals to the facultative feeding $M$. balthica (Table 4). Tissue $\mathrm{Cu}$ concentration was positively correlated to the $\mathrm{Cu} / \mathrm{Mn}$ ratio in sediments $\left(R^{2}=0.14 p<0.01 n=56\right)$, suggesting that the bioavailability of $C u$ is controlled by the amount of "reactive" Mn oxide, with increased levels of Mn tending to diminish the uptake and accumulation of $\mathrm{Cu}$ from the substrate. Tissue concentrations of $\mathrm{Zn}$ were related to the $\mathrm{Zn} /<63 \mu \mathrm{m}$ fraction ratio in sediments $\left(\mathrm{R}^{2}=0.13 \mathrm{p}<0.01 \mathrm{n}=56\right)$, indicating that the fine-grained fraction accounts for the bioavailability of sediment-bound $\mathrm{Zn}$. Soft tissue $\mathrm{Zn}$ was also significantly correlated with the $\mathrm{Zn}$ concentration in the particulate fraction in the overlying water $\left(R^{2}=0.12 p<0.05 n=27\right)$. The concentration of $M n$ in the clams was linearly related to three different environmental metal concentrations: (1) particulate-bound fraction $\left(R^{2}=0.19\right.$ $p<0.05 n=27)$, (2) Mn in sediments $\left(R^{2}=0.42 p<0.001 n=56\right)$ and (3) the ratio of $M n / F e$ in sediments $\left(R^{2}=0.38 p<0.001 n=56\right)$ that may imply that $M n$ is taken up in the Baltic clam through different pathways. The concentration of $\mathrm{Pb}$ in the bivalves was positively correlated with the ratio of $\mathrm{Pb} /$ organic component of $<63 \mu \mathrm{m}$ fraction in sediments $\left(\mathrm{R}^{2}=0.11 \mathrm{p}<0.016\right.$ $n=54)$. The removal of the results for $S W 60$ from the regression improved the $R^{2}$ value to $0.12(p<0.010 n=48)$ so metal uptake in the deep-water part of the plume is presumably distinct from that in the shallower parts and/or the bioavailability of $\mathrm{Pb}$ in this region can be different. Nickel was the only element which exhibited a positive correlation between the soft tissue metal concentration and its dissolved phase $\left(R^{2}=0.17 p<0.05 n=27\right)$. No relation of Fe in M. balthica with any of its environmental fractions measured was found.

\section{Discussion}

\subsection{Bioavailability of metals}

Bioavailable metals in the marine environment may correspond primarily to soluble phases and the phases which are weakly associated with ingested particles (Rainbow \& Phillips, 
Sokolowski et al. Metal sources to the Baltic clam Macoma balthica in southern Baltic Sea

1993; Rainbow, 1995). These fractions represent metal forms, which can pass across permeable body epithelia or alimentary tract epithelia after digestion. The chemical nature of the metals in the environment depends greatly on external physiochemical factors and thus they are susceptible to high spatio-temporal variations. The recognition of the contamination profiles in different regions with the aim to define the local geographical variation of trace metal bioavailabilities and to assess the effects of the metals on the resident (indigenous) biota requires therefore site-specific studies. Literature addressing profiles of metal bioavailability in various geographical regions is growing as these data are a baseline for coastal monitoring programmes of metal pollution against which future changes in metal levels in the marine environment can be established (e.g. in the Hong Kong coastal waters (Blackmore, 1998), British coastal waters (Philips \& Rainbow, 1993) and San Francisco Bay (Hornberger, Luoma, Cain, Parchaso, Brown, Bouse et al., 2000).

On the basis of direct measurements of three metal forms that might contribute to the total package of bioavailable metal, namely dissolved, labile particulate- and labile sedimentbound fractions, the profile of trace metal bioavailability in the Gulf of Gdansk has been established. The SW10 and SW20 were often the sites with the highest extractable trace metal concentrations (Fig. 2-5), highlighting the importance of the Vistula River as a source of metals into the Gulf. Since the Gulf receives a huge input of freshwater with the river, which drains ca $54 \%$ of the area of Poland including the major industrial regions and cities of Katowice, Krakow and Warsaw, not surprisingly the Vistula is considered to be an important source of trace metals to the Gulf (Rainbow, Fialkowski, Sokolowski, Smith, \& Wolowicz, 2004; Szefer, 2002). The concentrations of all three metal fractions at the two mid-deep sites (SW30 and SW40) were generally low with exception of particulate $\mathrm{Pb}$ and $\mathrm{Zn}$, the levels of which were elevated. Physical processes of dilution and dispersion, that are intense in the mixing zone of fresh riverine and brackish waters, can directly explain such a distribution pattern. This is also consistent with the border of the low salinity zone and the extent of the riverine water impact based on horizontal and vertical reduced salinity to be at the distance of $3-4 \mathrm{~km}$ from the river mouth. At SW60 concentrations of dissolved and particulate metals 
Sokolowski et al. Metal sources to the Baltic clam Macoma balthica in southern Baltic Sea

increased, most pronounced for $\mathrm{Cu}$, Fe and Ni (Fig. 2-4), possibly due to benthic fluxes through desorption from detrital and/or resuspended particles. Other mechanisms accounting for enrichment of $\mathrm{Fe}$ and $\mathrm{Ni}$ include reductive dissolution of $\mathrm{Fe}$ oxyhydroxides resulting in a release of dissolved Ni (Sokolowski, Wolowicz, \& Hummel, 2001). Metal concentrations in the surficial sediments at this site remained at a similar (low) level to the mid-deep sites. However, regarding the high contribution of the $<63 \mu \mathrm{m}$ fraction in sediments at SW60 (on average $69.4 \%$; Table 2), hypoxic/anoxic conditions and the presence (temporal) of hydrogen sulphide, phenomena often observed in deeper parts of the Baltic Sea (Janas \& Szaniawska, 1996), the overall metal bioavailability at SW60 from the substratum can be assessed high.

In addition to geographical differences in the extractable concentrations of the trace metals, there were also changes in time over the period of sampling. Comparisons against future data sets need therefore to allow for temporal effects (Rainbow, Fialkowski, Sokolowski, Smith, \& Wolowicz, 2004).

\subsection{Metals in clams}

Accumulated metal concentrations in bivalves are integrated records of the metals taken up from all sources over a particular period. These concentrations are a measure of the recent bioavailability of the metal and are the results of complex and interrelated hydrological, physico-chemical and biological factors (Rainbow, 1996).

In the Gulf of Gdansk, a similar distribution pattern of tissue accumulated $\mathrm{Cu}$ and $\mathrm{Zn}$ in space suggests that the accumulation mechanisms of these metals in $M$. balthica can be similar. However, the highest concentrations of $\mathrm{Cu}$ and $\mathrm{Zn}$ in the clams at SW30 and SW40 corresponded with relatively low environmental extractable metal concentrations. Biologically controlled processes likely account for the increased accumulated metal concentrations. One explanation can be that they are essential elements and play an important physiological role.

Seasonal fluctuations of tissue metal concentrations provide further support to the regulation of body concentrations of $\mathrm{Zn}$ but not $\mathrm{Cu}$. Variations in $\mathrm{Zn}$ concentrations in the clams (higher 
Sokolowski et al. Metal sources to the Baltic clam Macoma balthica in southern Baltic Sea

levels in winter and summer and lower during spring and autumn) were opposite to changes in body weight and physiological state of the organism, suggesting a dilution/concentration effect of body weight (Sokolowski, Bawazir, \& Wolowicz, 2004). The tissue concentration of $\mathrm{Ni}$ exhibited a reverse distribution pattern to $\mathrm{Cu}$ and $\mathrm{Zn}$, but no clear temporal trends were apparent. It is therefore possible, that $\mathrm{Ni}$ accumulation in the clams depends mostly on environmental concentrations. The concentration of Fe in $M$. balthica increased gradually along the transect studied with a maximum in the deeper parts of the plume. Iron behaviour in marine bivalves is generally considered to reflect the influence of both biotic and abiotic factors, a relative effect of a given factor being species-specific (Kumari, Kaisary, \& Rodrigues, 2006). Tissue concentrations of Mn tended to increase with depth, and from the near-shore site to the deepest site, that generally agrees with a gradient of hydrological parameters such as temperature, dissolved oxygen concentration and salinity in the Gulf of Gdansk (Sokolowski, Wolowicz, \& Hummel, 2001). Coincidentally, the tissue concentrations of $\mathrm{Mn}$ corresponded also with its particulate-bound and sediment concentrations, indicating that the metal accumulation is largely influenced by its external concentration and environmental factors. The distribution profile for $\mathrm{Pb}$ was intermediate; increased concentrations occurred at SW20 and SW30 to diminish gradually towards the deep-water zone, suggesting the importance of external factors in controlling $\mathrm{Pb}$ concentrations in $M$. balthica.

\subsection{Routes of metal uptake}

Macoma balthica lives preferentially burrowed in sediments and uses long extensible siphons to vacuum up particles from the surface of the substrate or overlying water (Zwarts \& Wanink, 1989). The bivalve is generally considered a deposit-feeder, but is also able to filter suspended material from the water column (Absil, Kroon, \& Wolterbeek, 1994). Thus, dissolved and particulate metals as well as metal associated with bottom sediments offer potential sources of trace metals to this infaunal bivalve. 
Sokolowski et al. Metal sources to the Baltic clam Macoma balthica in southern Baltic Sea

Copper in the bivalve tissue was correlated with the $\mathrm{Cu} / \mathrm{Mn}$ ratio in sediments (Table 4). Sediment Mn components are presumably modifying what $\mathrm{Cu}$ species is bioavailable for uptake, possibly through an inhibitory effect of $\mathrm{Mn}$ oxyhydroxides (Bendell-Young, Chouinard, \& Pick, 1994). Low concentrations of $\mathrm{Cu}$ in $\mathrm{M}$. balthica near-shore indeed corresponded to high sediment concentrations of $\mathrm{Mn}$, and elevated concentrations of $\mathrm{Cu}$ were observed in a deep-water region of low extractable $\mathrm{Mn}$ in the sediments. In the deepwater region, a high fine-grained fraction and organic content in sediments (Table 2) apparently contributed to the increased metal accumulation in the clam (Hummel, Magni, Amiard-Triquet, Rainglet, Modderman, van Duijn, et al., 1998). The importance of surficial sediments as a source of $\mathrm{Cu}$ to $M$. balthica has also been highlighted in the North Sea (Hummel, Modderman, Amiard-Triquet, Rainglet, van Duijn, Herssevoort, et al., 1997) and San Francisco Bay (Cain \& Luoma, 1990).

The accumulated tissue concentration of $\mathrm{Zn}$ was proportional to the $\mathrm{Zn} /<63 \mu \mathrm{m}$ fraction ratio in sediments (Table 4), suggesting that the fine-grained fraction acts as a modifier of $\mathrm{Zn}$ uptake, and higher tissue concentrations of $\mathrm{Zn}$ can be expected at sites rich in sedimentbound $\mathrm{Zn}$ and/or poor in the $<63 \mu \mathrm{m}$ fraction. However, an increased tissue $\mathrm{Zn}$ concentration at SW30 and SW40 coincided with low concentrations of Zn in sediments and a decreased percentage of the fine-grained fraction (correlation coefficients between tissue $\mathrm{Zn}$ and $\mathrm{Zn}$ in sediments, and between tissue $\mathrm{Zn}$ and the percentage of $<63 \mu \mathrm{m}$ fraction were $\mathrm{R}^{2}=0.05$ $p<0.10 n=56$ and $R^{2}=0.02 p<0.27 n=57$, respectively). Possible explanations for these contradictory findings are: (1) the bioavailability to benthic fauna of $\mathrm{Zn}$ from the sediments is controlled by other environmental factors (e.g. by Fe oxyhydroxides) and/or (2) uptake of $\mathrm{Zn}$ from the sediments and/or its subsequent accumulation is regulated by the organism. The importance of sediment geochemistry on tissue $\mathrm{Zn}$ accumulation in marine bivalves is poorly documented (e.g. Griscom, Fisher, \& Luoma, 2000), while regulation of body Zn concentrations has been shown in some but not all bivalve species (Mason \& Jenkins, 1995; Rainbow, 1996). Zinc in M. balthica from the Gulf of Gdansk was also positively correlated to metal concentration in the suspended particulate matter (Table 4), providing an alternative 
Sokolowski et al. Metal sources to the Baltic clam Macoma balthica in southern Baltic Sea

metal source (Ross, Bidwell, Wiliams, \& Boland, 2003). The higher tissue Zn concentrations indeed corresponded to higher particulate-bound Zn concentrations in the overlying water, but extractable metal concentrations in the suspended particulate matter were not as high as would be consistent with net $\mathrm{Zn}$ accumulation in the bivalves. Therefore, the clams likely assimilate both particulate- and sediment-bound fractions of $\mathrm{Zn}$ in the southern Baltic Sea. A dual dietary source of metals for $\mathrm{Zn}$ in the Gulf contrasts the results of Harvey and Luoma (1985) who showed the relative importance of water as a dominant exposure pathway in $M$. balthica. It is therefore concluded that partial biological regulation of the metal in the clam can account for low $\mathrm{Zn}$ variations in the tissue, making metal soft tissue accumulated concentration, to some degree, independent of its external level. This is in a good agreement with the fact that $\mathrm{Zn}$ is an essential element and is involved in a number of metabolic processes.

The concentration of $\mathrm{Mn}$ in the soft tissues of $M$. balthica correlated with extractable $\mathrm{Mn}$ concentrations in sediments and the $\mathrm{Mn} / \mathrm{Fe}$ ratio in sediments. Manganese associated with surficial sediments represents a considerable source of this metal to the clams and reflects the importance of Fe hydroxides in the partitioning of $\mathrm{Mn}$ in the sediments of the Gulf, as also postulated by Szefer, Glasby, Pempkowiak, \& Kaliszan (1995). An increase of $\mathrm{Fe}$ oxyhydroxides inhibits the bioavailability of $\mathrm{Mn}$ from sediments by reducing its lability through stronger binding to deposited particles (Gerringa, 1991). Accumulated tissue Mn concentration was also correlated with the particulate-bound metal concentration, implying that this phase can also contribute to $\mathrm{Mn}$ accumulation. Assimilation of $\mathrm{Mn}$ in marine bivalves takes place primarily following ingestion and digestion in digestive glands where the concentration of $\mathrm{Mn}$ can reach up to $35 \mu \mathrm{g}$ dry $\mathrm{wt}^{-1}$ (Irato, Santovito, Cassini, Piccinni, \& Albergoni, 2003).

Organic components of the sediments can be an important modifying factor for $\mathrm{Pb}$ bioavailability and uptake by the clams, as the tissue concentration of $\mathrm{Pb}$ was correlated with the ratio of $\mathrm{Pb} /$ organic component in sediments (Table 4). Thomas and Bendell-Young (1998) found that the availability of Pb to two closely related clams Scrobicularia plana and 
Sokolowski et al. Metal sources to the Baltic clam Macoma balthica in southern Baltic Sea

M. balthica was controlled mainly by metal concentration in sediments extracted with a weak acid digestion. The distribution pattern of tissue $\mathrm{Pb}$ concentrations in the Gulf of Gdansk corresponded well with the profile of extractable $\mathrm{Pb}$ concentrations in sediments $\left(\mathrm{R}^{2}=0.11\right.$, $p<0.016)$. Excluding the values for the deepest site $S W 60$ from the analysis improved $R^{2}$ to $0.12(\mathrm{p}<0.011)$, indicating presumably different behaviour of $\mathrm{Pb}$ in sediments of the deepwater region. In deeper stagnated waters of the Baltic, mineralisation of organic matter through biological catalysed processes under low oxygen conditions results in hypoxia and even anoxia, leading often to the production of hydrogen sulphide (Janas \& Szaniawska, 1996). The presence of as low as $1.8 \%$ WW/WW of $\mathrm{H}_{2} \mathrm{~S}$ reduces the mobility of $\mathrm{Pb}$ from surficial sediments and particulate matter by binding to non-reactive PbS (Bourgoin, Risk, \& Aitken, 1991). Reduced lability of $\mathrm{Pb}$ due to association with Fe oxyhydroxides in deeper sediments provides another explanation as $\mathrm{Fe}$ oxyhydroxides inhibit $\mathrm{Pb}$ assimilation in some sediment-dwelling bivalves such Eliptio complanata (Tessier, Campbel, Auclair, \& Bisson, 1984).

Nickel was the only element whose concentration in $M$. balthica was positively correlated with dissolved metal concentration, highlighting the importance of the dissolved fraction in metal accumulation. A similar assimilation mechanism was also suggested for a typical suspension feeder Dreissena polymorpha (Klerks \& Fraleigh, 1997), although a second metal uptake pathway from sediments cannot be excluded (Kumblad, Bradshaw, \& Gilek, 2005). Uptake of Ni from solution can appear thus to be an important uptake pathway for benthic bivalves. This agrees with a very low affinity of $\mathrm{Ni}$ for particulate matter in marine and estuarine waters (Brügmann, Bernard, \& van Grieken, 1992; Chiffoleau, Cossa, Auger, \& Truquet, 1994). Even in the presence of a high concentration of particulate matter Ni exists preferentially in the dissolved phase which can contribute to the total load of the metal in the water column (dissolved $+1 \mathrm{M} \mathrm{HCl}$ extractable particulate fractions) in the Vistula River plume up to $96 \%$ (Sokolowski, Wolowicz, \& Hummel, 2001).

Iron concentrations in the tissues did not correlate with any of the extractable metal concentrations measured. Possible causes for a lack of any relationship would include the 
Sokolowski et al. Metal sources to the Baltic clam Macoma balthica in southern Baltic Sea

metal origin and behaviour in the marine environment, and the functional role that iron plays in organisms. In the southern Baltic, iron has a natural origin and is released to the sea by natural erosion processes in the catchment area of the Vistula (Szefer, 2002; Szefer, Glasby, Pempkowiak, \& Kaliszan, 1995). Once in the sea, iron is very insoluble in water and exists mainly in a form associated with lithogenic particles. High sediment bioavailability of $\mathrm{Fe}$ is therefore found in regions of elevated contribution of lithogenic non-organic material. In addition, $\mathrm{Fe}$ is an essential metal, present in bivalve's tissues primarily in a metabolically available form required in cytochromes and haemoglobin of marine invertebrates (Rainbow, 1996) that plausibly affects its concentration in an organism. The conclusion stands out that iron levels in southern Baltic are likely not in excess of metabolic requirements of the clams, making its tissue metal concentrations (although variable with sites) in equilibrium with environmental levels. It is therefore not surprising that separation of the routes of Fe uptake in $M$. balthica, based on measurements of metal concentrations in various compartments of the environment, appeared complex.

\section{Conclusions}

Measurements of dissolved metals and the easily extractable (by $1 \mathrm{M} \mathrm{HCl)}$ ) fraction of particulate-bound metals in the overlying water and surficial sediments $(<63 \mu \mathrm{m})$ permitted three main potentially bioavailable metal sources to be defined. Regression of metal data vs. metal concentrations in the soft tissue of Macoma balthica enable different metal uptake sources to the Baltic clam to be identified. Surficial sediments and particulate matter appeared to contribute mostly in metal accumulation in $M$. balthica. Copper and $\mathrm{Pb}$ are primarily assimilated from surficial sediments, $\mathrm{Zn}$ and $\mathrm{Mn}$ can be taken up from both suspended and deposited particles, while solution is the principal source of Ni. The uptake of Cu from sediments is controlled by Mn components possibly through an inhibitory effect of $\mathrm{Mn}$ oxyhydroxides, and $\mathrm{Pb}$ depends on the sediment organic components. In deep-water areas, the accessibility of $\mathrm{Pb}$ from sediments might be additionally inhibited by hydrogen 
Sokolowski et al. Metal sources to the Baltic clam Macoma balthica in southern Baltic Sea

sulphide due to binding to non-reactive $\mathrm{PbS}$. Tissue accumulation of $\mathrm{Zn}$ in the clams is postulated to be internally regulated by the animal, making $\mathrm{Zn}$ tissue concentrations, to some degree, independent of its environmental level. Partitioning of Mn in sediments was found to be mediated by the concentrations of labile Fe, with increased levels of Fe tending to inhibit the absorption of Mn by the bivalves.

\section{Acknowledgements}

This research was supported by internal grant (BW/1320-5-0173-9) to A.S. from the University of Gdansk and by a fellowship of Nederlandse Organisatie voor Internationale Samenwerking in het Hoger Onderwijs (NUFFIC) (IS.CV.PL.96/12866) to A.S. Joop Nieuwenhuize from NIOO-CEMO, Yerseke is gratefully acknowledged for his assistance during analyses of dissolved and particulate metals and Milosz Bialkowski for his help with metal analysis in the clams. This is publication no .... of NIOO, Centre for Estuarine and Marine Ecology, Yerseke, The Netherlands. 
Sokolowski et al. Metal sources to the Baltic clam Macoma balthica in southern Baltic Sea

\section{Reference}

Absil, M.C.P., Kroon, J.J., \& Wolterbeek, H.A.T. (1994). Availability of Cu from phytoplankton and water for the bivalve Macoma balthica. II. Uptake and elimination from ${ }^{64} \mathrm{Cu}$-labelled diatoms and water. Marine Biology, 118, 129-135.

Bendell-Young, L.I., Chouinard, J., \& Pick, F.R. (1994). Metal concentrations in chironomids in relation to peatland geochemistry. Archives of Environmental Contamination and Toxicology, 27, 186-194.

Blackmore, G. (1998). An overview of trace metal pollution in the coastal waters of Hong Kong. The Science of the Total Environment, 214, 21-48.

Blackmore, G., \& Wang, W.X. (2002). Uptake and efflux of Cd and Zn by the green mussel Perna viridis after metal preexposure. Environmental Science and Technology, 36, 989995.

Bourgoin, B.P., Risk, M.J.M., \& Aitken, A.E. (1991). Factors controlling lead availability to the deposit-feeding bivalve Macoma balthica in sulphide-rich sediments. Estuarine, Coastal and Shelf Science, 32, 625-632.

Brügmann, L., Bernard, P.C., \& van Grieken, R. (1992). Geochemistry of suspended matter from the Baltic Sea. 2. Results of bulk trace metal analysis by AAS. Marine Chemistry, 38, 303-323.

Bryan, G.W., \& Langston, W.J. (1992). Bioavailability, accumulation and effects of heavy metals in sediments with special references to United Kingdom estuaries: a review. Environmental Pollution, 76, 227-240.

Cain, D.J., \& Luoma, S.N. (1990). Influence of seasonal growth, age and environmental exposure on $\mathrm{Cu}$ and $\mathrm{Ag}$ in a bivalve indicator, Macoma balthica, in San Francisco Bay. Marine Ecology Progress Series, 60, 45-55.

Chiffoleau, J.F., Cossa, D., Auger, D., \& Truquet, I. (1994). Trace metal distribution, partition and fluxes in the Seine estuary (France) in low discharge regime. Marine Chemistry, 47, 145-158. 
Sokolowski et al. Metal sources to the Baltic clam Macoma balthica in southern Baltic Sea

Chong, K., \& Wang, W.X. (2000). Bioavailability of sediment-bound Cd, Cr, and Zn to the green mussel Perna viridis and the clam Ruditapes philippinarum. Journal of Experimental Marine Biology and Ecology, 255, 75-92

Decho, A.W., \& Luoma, S.N. (1996). Flexible digestion strategies and trace metal assimilation in marine bivalves. Limnology and Oceanography, 41, 568-572.

Gerringa, L.J.A. (1991). Mobility of $\mathrm{Cu}, \mathrm{Cd}, \mathrm{Ni}, \mathrm{Pb}, \mathrm{Zn}, \mathrm{Fe}$ and $\mathrm{Mn}$ in marine sediment slurries under anaerobic conditions and at $20 \%$ air saturation. Netherlands Journal of Sea Research, 27, 145-156.

Griscom, S.B., Fisher, N.S., \& Luoma, S.N. (2000). Geochemical influences on assimilation of sediment-bound metals in clams and mussels. Environmental Science and Technology, $34,91-99$

Harvey, R.W., \& Luoma, S.N. (1985). Separation of solute and particulate vectors of heavy metal uptake in controlled suspension-feeding experiments with Macoma balthica. Hydrobiologia, 121, 97-102.

Hornberger, M. I., Luoma, S. N., Cain, D. J., Parchaso, F., Brown, C. L., Bouse, R. M., Wellise, C., \& Thompson, J. K. (2000). Linkage of bioaccumulation and biological effects to changes in pollutant loads in south San Francisco Bay. Environmental Science and Technology, 34, 2401-2409.

Hummel, H., Modderman, R., Amiard-Triquet, C., Rainglet, F., van Duijn, Y., Herssevoort, M., de Jong, J., Bogaards, R., Bachelet, G., Desprez, M., Marchand, J., Sylvand, B., Amiard, J.C., Rybarczyk, H., \& de Wolf, L. (1997). A comparative study on the relation between copper and condition in marine bivalves and the relation with copper in the sediment. Aquatic Toxicology, 38, 165-181.

Hummel, H., Magni, P., Amiard-Triquet, C., Rainglet, F., Modderman, R., van Duijn, Y., Herssevoort, M., de Jong, J., Snitsevorg, L., Ytsma, M., Bogaards, R., \& de Wolf, L. (1998). Influence of the level of oxygenation in sediment and water on copper bioavailability to marine bivalves: laboratory experiments and translocation experiments in the field. Hydrobiologia, 373/374, 297-310. 
Sokolowski et al. Metal sources to the Baltic clam Macoma balthica in southern Baltic Sea

Irato, P., Santovito, G., Cassini, A., Piccinni, E., \& Albergoni, V. (2003). Metal accumulation and binding protein induction in Mytilus galloprovincialis, Scapharca inaequivalvis, and Tapes philippinarum from the Lagoon of Venice. Archives of Environmental Contamination and Toxicology, 44, 476-484.

Janas, U., \& Szaniawska, A. (1996). The influence of hydrogen sulphide on macrofaunal biodiversity in the Gulf of Gdansk. Oceanologia, 38, 127-142.

Klerks, P.L., \& Fraleigh, P.C. (1997). Uptake of nickel and zinc by the zebra mussel Dreissena polymorpha. Archives of Environmental Contamination and Toxicology, 32, 191-197.

Kramer, K.J.M., Brockman, U.H., \& Warwick, R.M. (1994). Tidal estuaries-Manual of Sampling and Analytical Procedures. Rotterdam: Balkema, A.A.

Kumari, K.L., Kaisary, S., \& Rodrigues, V. (2006). Bio-accumulation of some trace metals in the short-neck clam Paphia malabarica from Mandovi estuary, Goa. Environment International, 32, 229-234.

Kumblad, L., Bradshaw, C., \& Gilek, M. (2005). Bioaccumulation of ${ }^{51} \mathrm{Cr},{ }^{63} \mathrm{Ni}$ and ${ }^{14} \mathrm{C}$ in Baltic benthos. Environmental Pollution, 134, 45-56.

Luoma, S.N., \& Bryan, G.W. (1981). A statistical assessment of the forms of trace metals in oxidized estuarine sediments employing chemical extractants. The Science of the Total Environment, 17, 165-196.

Mason, A.Z., \& Jenkins, K.D. (1995). Metal detoxification in aquatic organisms. In A. Tessier, D.R. Turner (Eds.), Metal speciation and bioavailability in aquatic systems (pp. 479-608). West Sussex: Wiley.

Maurer, D., Gerlinger, T., Robertson, G., \& Nguyen, H. (1997). Trace metal bioaccumulation in soft-bottom macrobenthos from the San Pedro Shelf, California. Internationale Revue der gesamten Hydrobiologie, 82, 225-245.

Phillips, D. J. H., \& Rainbow, P. S. (1993). Biomonitoring of Trace Aquatic Contaminants. Barking: Elsevier. 
Sokolowski et al. Metal sources to the Baltic clam Macoma balthica in southern Baltic Sea

Rainbow, P.S. (1995). Biomonitoring of heavy metal availability in the marine environment. Marine Pollution Bulletin, 31, 183-192.

Rainbow, P.S. (1996). Heavy metals in aquatic invertebrates. In W.W. Beyer, G.H. Heinz, A.W. Redmon-Norwood (Eds.), Environmental contaminants in wildlife (pp. 405-425). SETAC Spec. Publ. Series, Pensacola: Lewis Publishers.

Rainbow, P.S. (2002). Trace metal concentrations in aquatic invertebrates: why and so what? Environmental Pollution, 120, 497-507.

Rainbow, P.S., \& Philips, D.J.H. (1993). Cosmopolitan biomonitors of trace metals. Marine Pollution Bulletin, 26, 593-601.

Rainbow, P.S., Philips, D.J.H, \& Depledge, M.H. (1990). The significance of trace metal concentrations in marine invertebrates. Marine Pollution Bulletin, 21, 321-324.

Rainbow, P.S., Fialkowski, W., Sokolowski, A., Smith, B.D., \& Wolowicz, M. (2004). Geographical and seasonal variation of trace metal bioavailabilities in the Gulf of Gdansk, Poland using mussels (Mytilus trossulus) and barnacles (Balanus improvisus) as biomonitors. Marine Biology, 144, 271-286.

Ross, K.E., Bidwell, J.R., Wiliams, M., \& Boland, J. (2003). Trace metals associated with seston collected from Spencer Gulf, South Australia, near a lead smelter: spatial distribution, temporal variability and uptake by bivalves. Transactions of the Royal Society of South Australia, 12, 33-45.

Shine, J.P., Ika, R., \& Ford, T.E. (1998). Relationship between oxygen consumption and sediment-water fluxes of heavy metals in coastal marine sediments. Environmental Toxicology and Chemistry, 17, 2325-2337.

Simkiss, K., \& Taylor, M.G. (1989). Metal fluxes across the membranes of aquatic organisms. Review in Aquatic Sciences, 1, 173-188.

Sokal, R.R., \& Rohlf, F.J. (1995). Biometry. New York: Freeman.

Sokolowski, A., Wolowicz, M., \& Hummel, H. (2001). Distribution of dissolved and labile particulate trace metals in the overlying water in the Vistula River plume (southern Baltic Sea). Marine Pollution Bulletin, 42, 967-980. 
Sokolowski et al. Metal sources to the Baltic clam Macoma balthica in southern Baltic Sea

Sokolowski, A., Bawazir, A.S., \& Wolowicz, M. (2004). The effect of seasonal cycle, weight and sex of individuals on trace metal concentrations in the brown mussel Perna perna from the coastal waters off Yemen (Gulf of Aden). Archives of Environmental Contamination and Toxicology, 46, 67-80.

Szefer, P. (2002). Metals, Metalloids and Radionuclides in the Baltic Ecosystem. Amsterdam: Elsevier.

Szefer, P., Glasby, G.P., Pempkowiak, J., \& Kaliszan, R. (1995). Extraction studies of heavymetal pollutants in surficial sediments from the southern Baltic Sea off Poland. Chemical Geology, 120, 111-126.

Tessier, A., Campbel, P.G.C., Auclair, J.C., \& Bisson, M. (1984). Relationship between the partitioning of trace metals in sediments and their accumulation in the tissues of the freshwater mollusc Elliptio complanata in a mining area. Canadian Journal of Fisheries and Aquatic Sciences, 41, 1463-1472.

Thomas, C.A., \& Bendell-Young, L.I. (1998). Linking the sediment geochemistry of an intertidal region to metal availability in the bivalve Macoma balthica. Marine Ecology Progress Series, 173, 197-213.

Wallace, W.G., Lee, B.-G., \& Luoma, S.N. (2003). Subcellular compartmentalization of Cd and $\mathrm{Zn}$ in two bivalves. I. Significance of metal-sensitive fractions (MSF) and biologically detoxified metal (BDM). Marine Ecology Progress Series, 249, 183-197.

Wang, W.-X. (2002). Interactions of trace metals and different marine food chains. Marine Ecology Progress Series, 243, 295-309.

Wang, W.-X., \& Fisher, N.S. (1999). Effects of calcium and metabolic inhibitors on trace element uptake in two marine bivalves. Journal of Experimental Marine Biology and Ecology, 236, 149-164.

Wang, W.-X., Yan, Q.-L., Fan, W., \& Xu, Y. (2002). Bioavailability of sedimentary metals from a contaminated bay. Marine Ecology Progress Series, 240, 27-38.

Zwarts, L., \& Wanink, J. (1989). Siphon size and burying depth in deposit- and suspensionfeeding benthic bivalves. Marine Biology, 100, 227-240. 
Sokolowski et al. Metal sources to the Baltic clam Macoma balthica in southern Baltic Sea

\section{Figure Captions}

Figure $\quad \underline{\text { Caption }}$

Fig. 1. Location of sampling sites $(\mathbf{\Delta})$

Fig. 2. Concentrations of dissolved metals $\left(\mu \mathrm{gl}^{-1}\right)$ in the overlying water in the Vistula River plume, April-September 1997 (after Sokolowski, Wolowicz, \& Hummel, 2001). Horizontal constant lines represent average values for all months at each site ( $n=5$ or 6 ) and horizontal dotted lines represent average value after excluding the extreme data from computations $(n=5)$. Data are presented as mean and standard error $(\mathrm{n}=3)$.

Fig. 3. Concentrations of $1 \mathrm{M} \mathrm{HCl}$ extractable fractions of particulate-bound metals (mg dry $\mathrm{wt}^{-1}$ for Fe and $\mu \mathrm{g}$ dry $\mathrm{wt}^{-1}$ for other metals) in the overlying water in the Vistula River plume, April-September 1997 (after Sokolowski, Wolowicz, \& Hummel, 2001). Horizontal lines represent average values for all months at each site $(n=6)$ and horizontal dotted lines represent average value after excluding the extreme data from computations $(n=5)$. Data are presented as mean and standard error $(n=3)$.

Fig. 4. Contents of $1 \mathrm{M} \mathrm{HCl}$ extractable fractions of particulate-bound metals $\left(\mu \mathrm{g} \mathrm{I}^{-1}\right)$ in the overlying water in the Vistula River plume, April-September 1997 (after Sokolowski, Wolowicz, \& Hummel, 2001). Horizontal lines represent average values for all months at each site $(n=6)$ and horizontal dotted lines represent average value after excluding the extreme data from computations $(n=5)$. Data are presented as mean and standard error $(n=3)$.

Fig. 5. Concentrations of $1 \mathrm{M} \mathrm{HCl}$ extractable fractions of sediment-bound metals (mg dry $\mathrm{wt}^{-1}$ for Fe and $\mu \mathrm{g}$ dry $\mathrm{wt}^{-1}$ for other metals) in the Vistula River plume, October 1996-September 1997. Horizontal lines represent average values for all months at each site $(n=12)$. Data are presented as mean and standard error $(n=3)$. 
Sokolowski et al. Metal sources to the Baltic clam Macoma balthica in southern Baltic Sea

Fig. 6. Metal concentrations in Macoma balthica ( $\mu \mathrm{g}$ dry $\mathrm{wt}^{-1}$ ) in the Vistula River plume, October 1996-September 1997. Horizontal lines represent average values for all months at each site $(10 \leq n \leq 12)$. Data are presented as mean and standard error $(n=3)$. 
Sokolowski et al. Metal sources to the Baltic clam Macoma balthica in southern Baltic Sea

Table 1. Comparison of mean $( \pm 95 \% \mathrm{CL}, \mathrm{n}=3)$ measured in this study and certified $( \pm 95 \%$ Tolerance Limits) trace metal concentrations $\mathrm{Cu}, \mathrm{Fe}, \mathrm{Mn}, \mathrm{Ni}, \mathrm{Pb}$ and $\mathrm{Zn}$ (mg dry $\mathrm{wt}^{-1}$ for $\mathrm{Fe}$ and $\mu \mathrm{g}$ dry $\mathrm{wt}^{-1}$ for other metals) in certified reference materials (Estuarine Sediments MESS-2 and Lobster Hepatopancreas TORT-1, NRC-INMS, Canada) along with data on recovery, coefficient of variation (CV: standard deviation/average 100) and the limit of detection (LOD: the standard deviation of the blank 3).

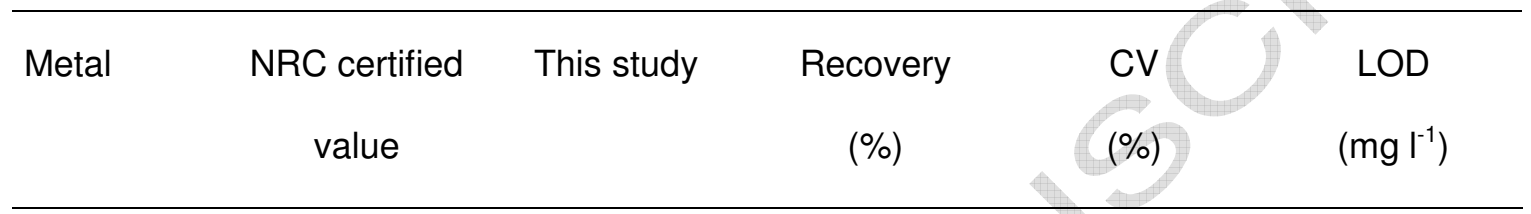

\section{MESS-2}

$\mathrm{Cu}$

$$
39.3 \pm 2.0
$$

$41.2 \pm 0.6$

105

1.5

0.064

$\mathrm{Fe}$

$6.22 \pm 0.31$

$7.14 \pm 1.27$

115

17.8

0.771

$\mathrm{Mn}$

$365 \pm 21$

$327 \pm 19$

90

2.5

0.236

$\mathrm{Ni}$

$49.3 \pm 1.8$

$52.8 \pm 1.9$

107

7.0

0.126

$\mathrm{Pb}$

$21.9 \pm 1.2$

$26.6 \pm 0.2$

122

0.8

0.183

$\mathrm{Zn}$

$172 \pm 16$

$182 \pm 17$

106

1.2

0.027

\section{TORT-1}

\begin{tabular}{|c|c|c|c|c|c|}
\hline $\mathrm{Cu}$ & 10 & $103 \pm 2$ & 97 & 1.9 & 0.043 \\
\hline $\mathrm{Fe}$ & \pm 13 & $113 \pm 12$ & 108 & 9.7 & 0.364 \\
\hline $\mathrm{Mn}$ & $13.6 \pm 1.2$ & $14.5 \pm 0.3$ & 107 & 1.9 & 0.030 \\
\hline $\mathrm{Ni}$ & $2.50 \pm 0.19$ & $2.20 \pm 0.03$ & 88 & 1.3 & 0.102 \\
\hline $\mathrm{Pb}$ & $0.35 \pm 0.13$ & $0.33 \pm 0.10$ & 94 & 3.0 & 0.088 \\
\hline $\mathrm{Zn}$ & $180 \pm 6$ & $155 \pm 4$ & 86 & 2.6 & 0.079 \\
\hline
\end{tabular}


Sokolowski et al. Metal sources to the Baltic clam Macoma balthica in southern Baltic Sea

Table 2. The percentage contribution of the $<63 \mu \mathrm{m}$ fraction in surficial sediments (\%) and the contribution of organic component in the fraction (\%) in the Vistula River plume, October 1996-September 1997.

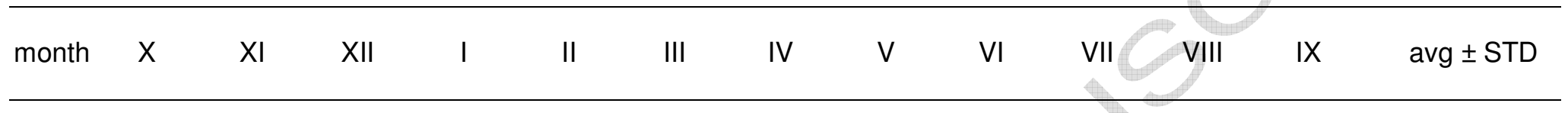

\section{Percentage contribution of $<63 \mu \mathrm{m}$ fraction}

\begin{tabular}{|c|c|c|c|c|c|c|c|c|c|c|c|c|c|}
\hline SW10 & 5.1 & 8.5 & 5.5 & 19.0 & 7.1 & 7.6 & 4.7 & 4.6 & 83.7 & 24.1 & 63.9 & 24.6 & $21.6 \pm 25.9$ \\
\hline SW20 & 15.7 & 38.3 & 21.0 & 23.1 & 27.9 & 20.4 & 21.1 & 22.6 & 24.9 & 24.1 & 25.0 & 12.9 & $23.1 \pm 6.3$ \\
\hline SW30 & 2.4 & 3.3 & 1.3 & 4.3 & 6.8 & 6.1 & 3.8 & 5.7 & 4.2 & 5.7 & 4.0 & 3.1 & $4.2 \pm 1.6$ \\
\hline SW40 & 15.9 & 3.0 & 12.2 & 14.0 & 1.8 & 11.7 & 17.7 & 0.6 & 0.6 & 0.3 & 0.4 & 7.0 & $7.1 \pm 6.8$ \\
\hline W60 & 68.0 & 70.5 & 71.4 & 71.4 & 66.4 & 73.4 & 63.1 & 62.0 & 67.8 & 73.4 & 66.4 & 78.9 & $69.4 \pm 4.8$ \\
\hline
\end{tabular}

\section{Organic component of the $<63 \mu \mathrm{m}$ fraction}

\begin{tabular}{lccccccccccccc} 
SW10 & 7.8 & 9.0 & 10.5 & 11.7 & 10.5 & 0.4 & 11.8 & 3.1 & 16.8 & 12.9 & 13.0 & 9.0 & $9.7 \pm 4.4$ \\
SW20 & 12.5 & 11.5 & 4.1 & 10.7 & 11.9 & 5.4 & 11.0 & 7.2 & 10.9 & 10.7 & 8.0 & 8.6 & $9.4 \pm 2.7$ \\
SW30 & 7.0 & 8.2 & 3.2 & 7.8 & 6.2 & 4.9 & 9.2 & 5.6 & 6.7 & 8.9 & 6.2 & 6.5 & $6.7 \pm 1.7$ \\
SW40 & 4.2 & 7.5 & 5.5 & 4.0 & 6.1 & 2.1 & 9.9 & 3.2 & 6.2 & 8.4 & 8.8 & 7.1 & $6.1 \pm 2.4$ \\
SW60 & 10.4 & 6.7 & 7.6 & 10.1 & 8.1 & 6.5 & 6.9 & 4.0 & 5.2 & 9.4 & 6.2 & 4.3 & $7.1 \pm 2.1$ \\
\hline
\end{tabular}


Sokolowski et al. Metal sources to the Baltic clam Macoma balthica in southern Baltic Sea

Table 3. Effects of month and site on metal concentrations in the overlying water (dissolved and easily extractable particulate-bound fractions), surficial sediments (easily extractable fraction) and the soft tissues of Macoma balthica (two-way ANOVA; ${ }^{*} p<0.05,{ }^{* *} p<0.01$, ${ }^{* * *} p<0.001$, blank space - not significant $\left.\pm 95 \% C L\right)$. The same effects were evident for the content and the concentration of particulate-bound metals in the water.

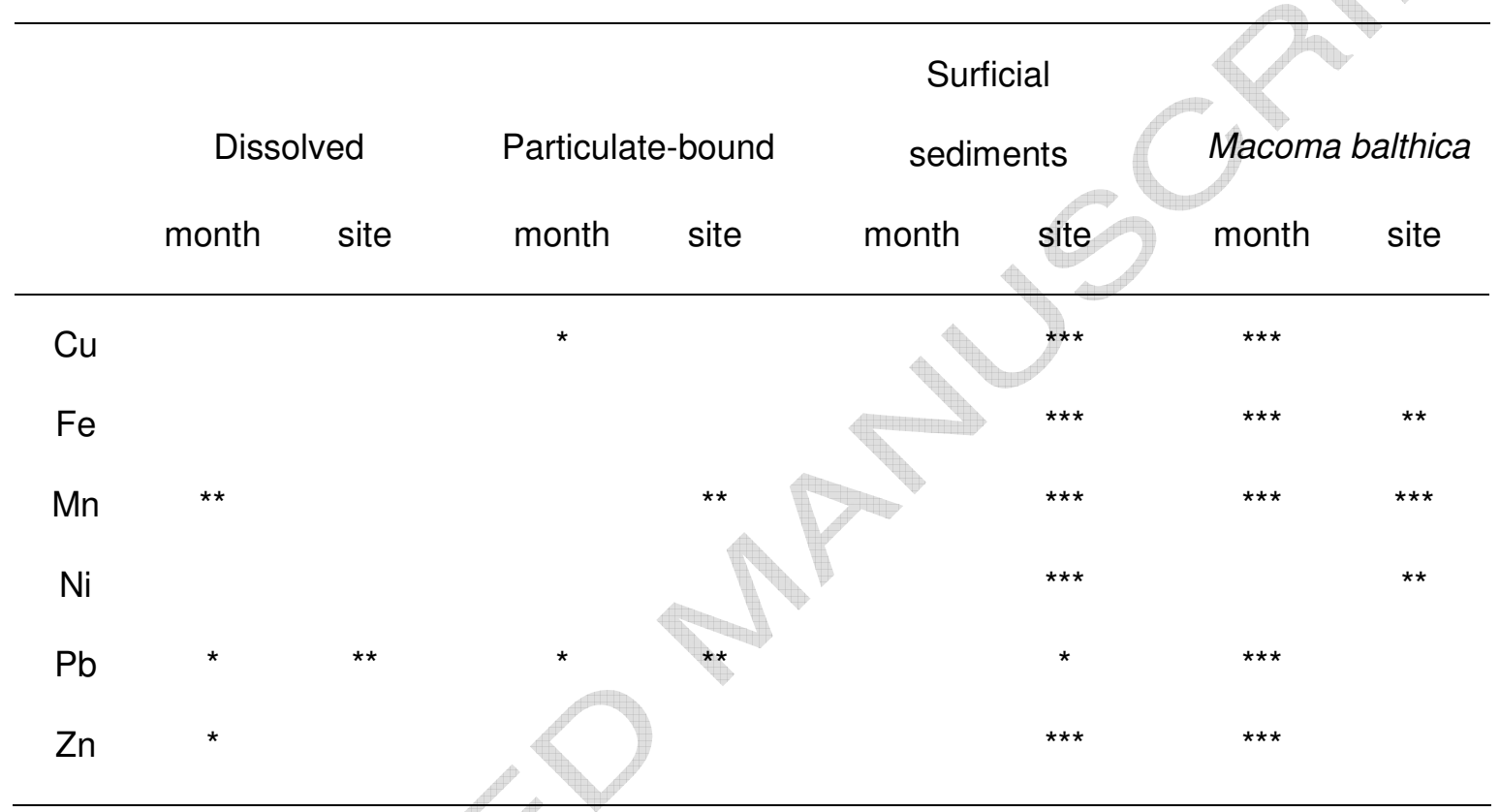


Sokolowski et al. Metal sources to the Baltic clam Macoma balthica in southern Baltic Sea

Table 4. Summarised results of the linear regression between different bioavailable metal fractions in the environment and metal concentrations in the soft tissue of Macoma balthica in the Gulf of Gdansk, southern Baltic Sea. Sediment metals were additionally normalised for the effect of concentrations of labile forms of $\mathrm{Fe}$ and $\mathrm{Mn}$, the percentage contribution of $<63 \mu \mathrm{m}$ fraction and its organic component $\left({ }^{*} \mathrm{p}<0.05,{ }^{* *} \mathrm{p}<0.01\right.$, ${ }^{* * *} p<0.001$, blank space - not significant $\pm 95 \% \mathrm{CL}$, - negative relation, + positive relation)

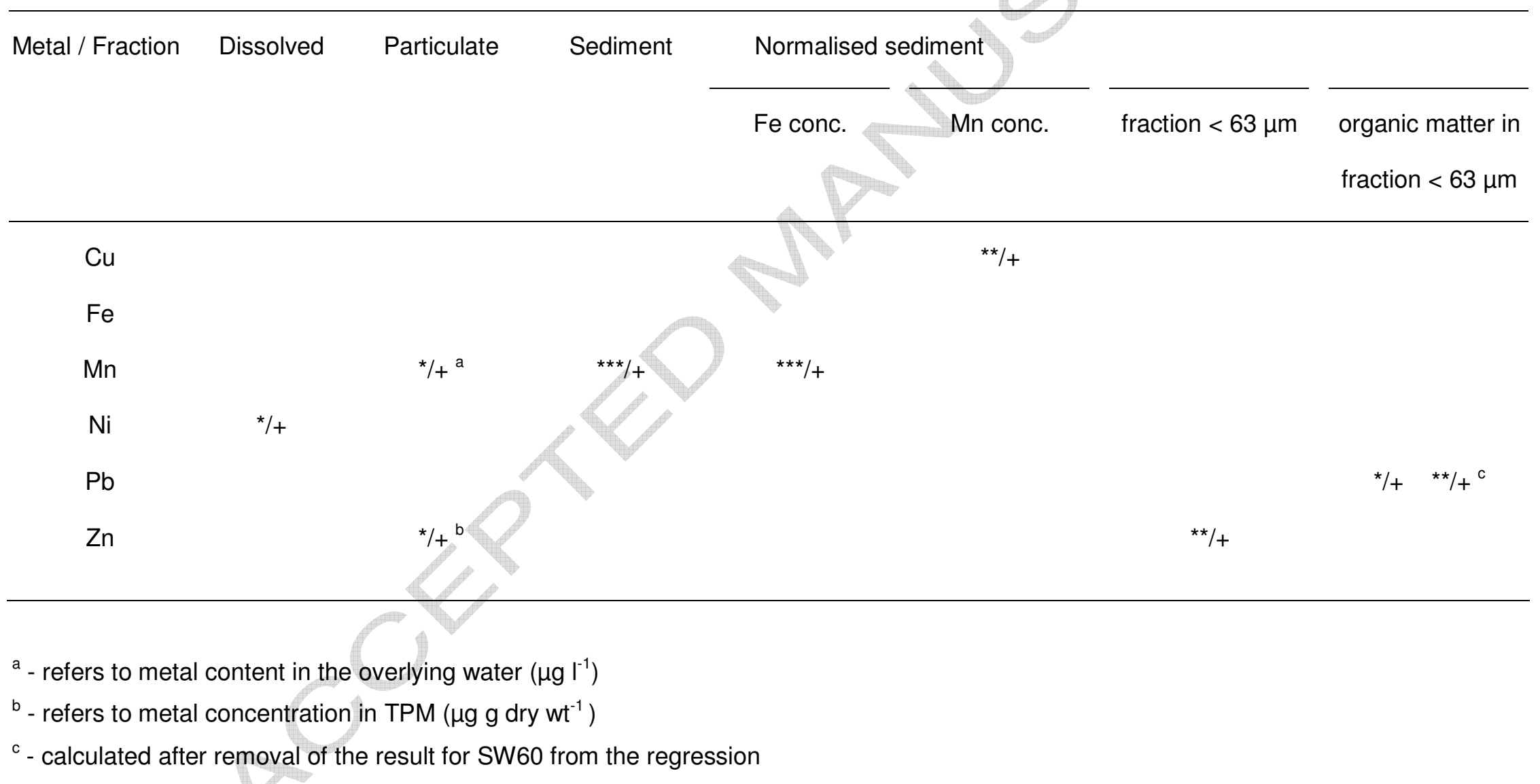


Sokolowski et al. Metal sources to the Baltic clam Macoma balthica in southern Baltic Sea

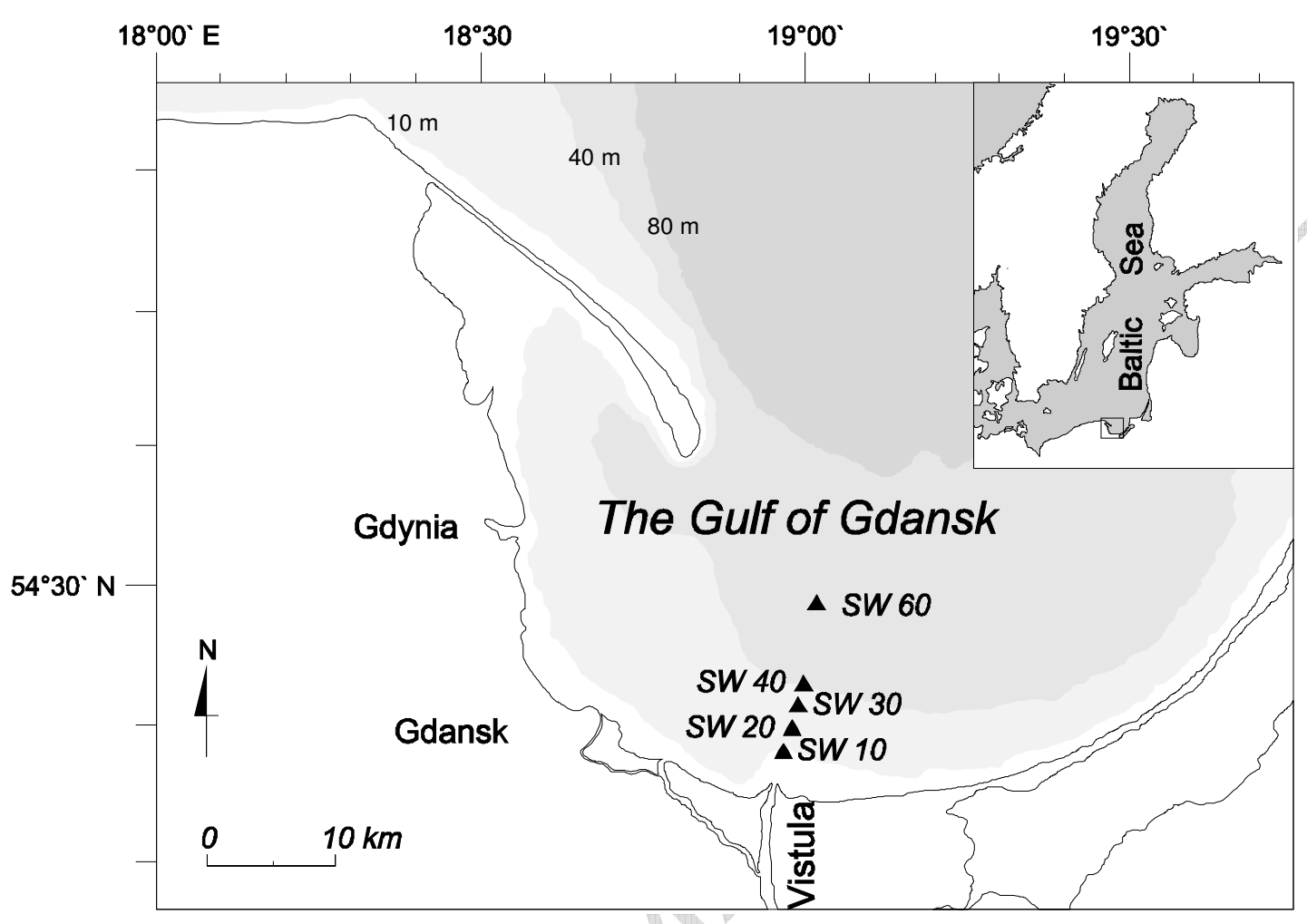

Fig. 1. 
Sokolowski et al. Metal sources to the Baltic clam Macoma balthica in southern Baltic Sea

Cu

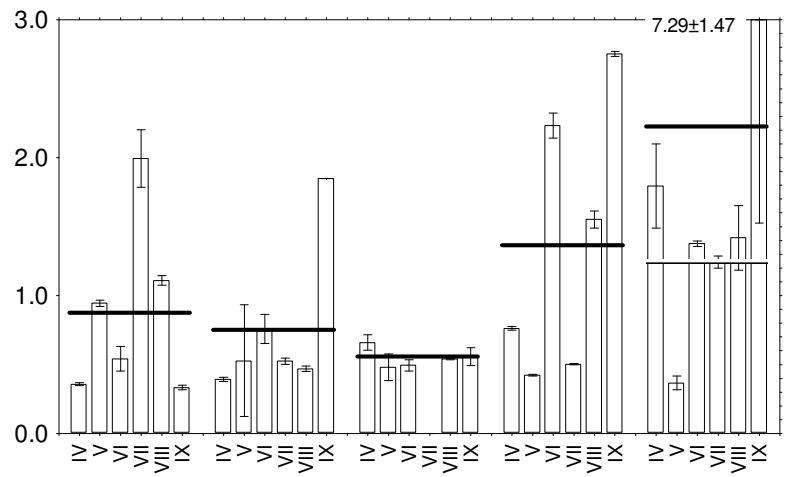

$\mathrm{Ni}$

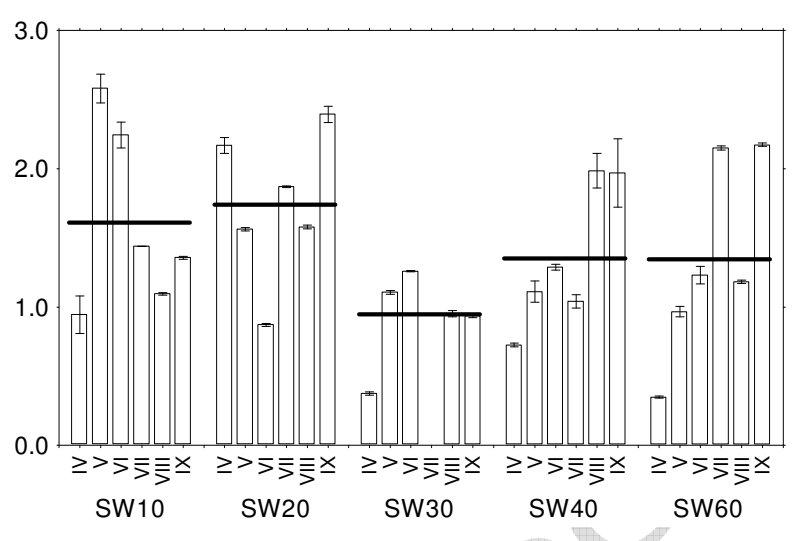

\section{Fe}

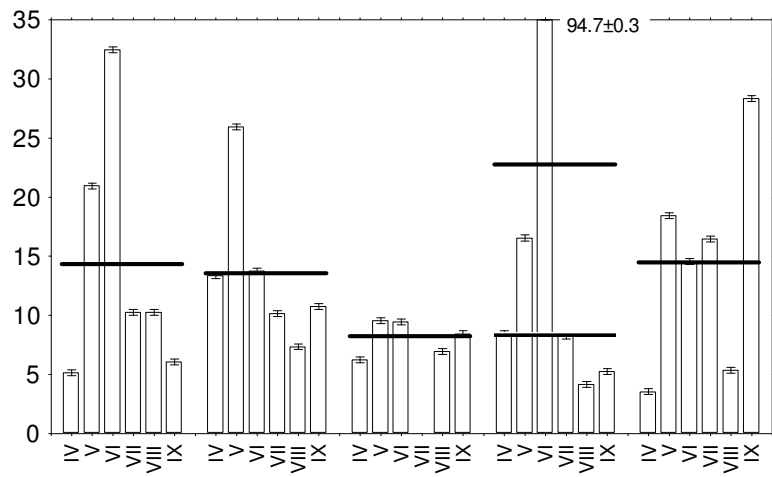

$\mathrm{Pb}$

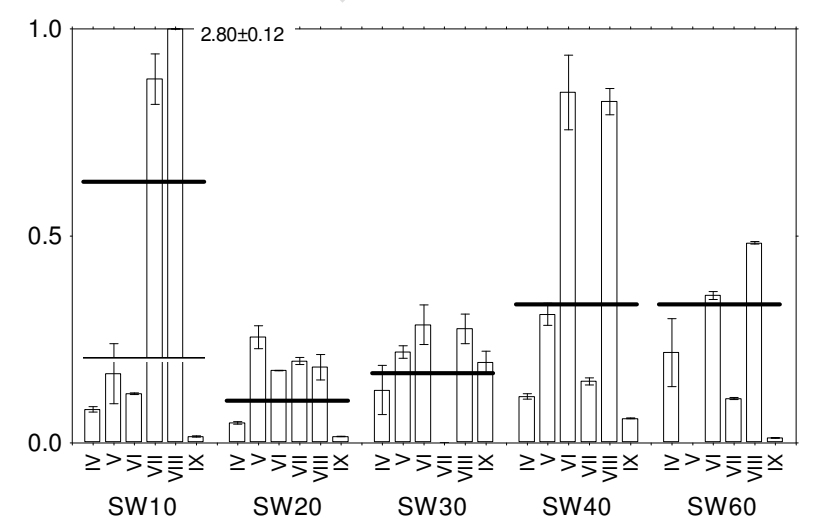

\section{Mn}

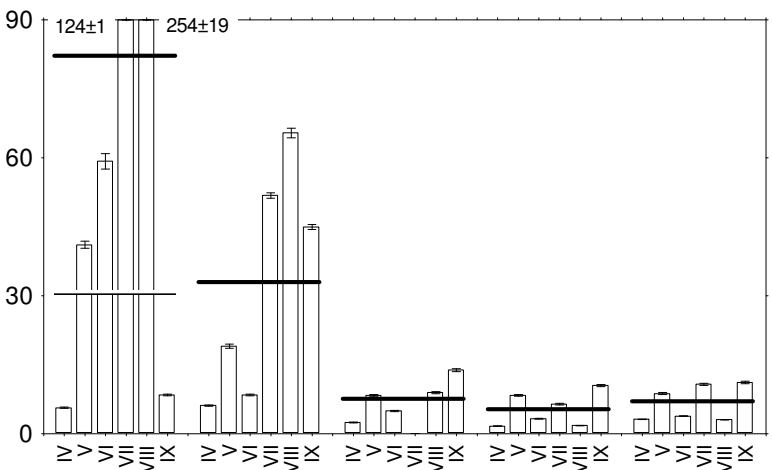

$\mathrm{Zn}$

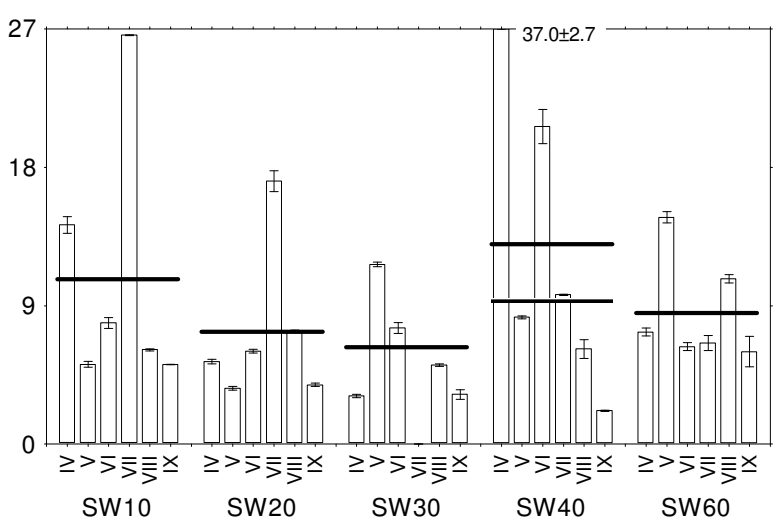

Fig. 2. 
Sokolowski et al. Metal sources to the Baltic clam Macoma balthica in southern Baltic Sea

Cu

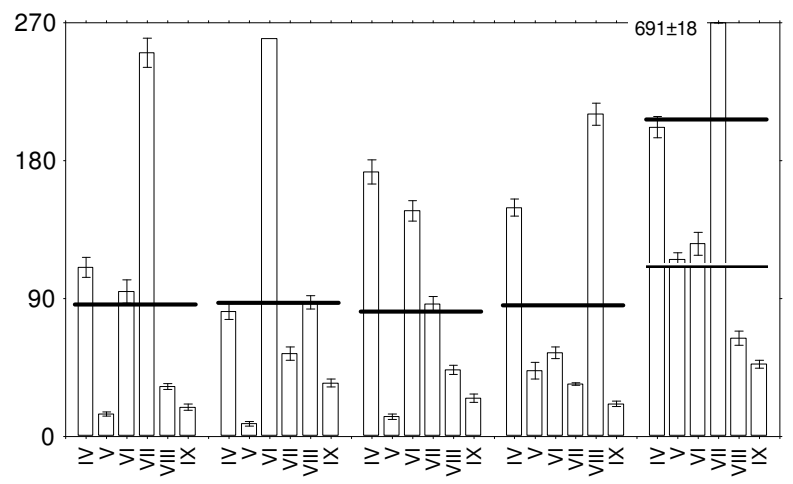

Ni

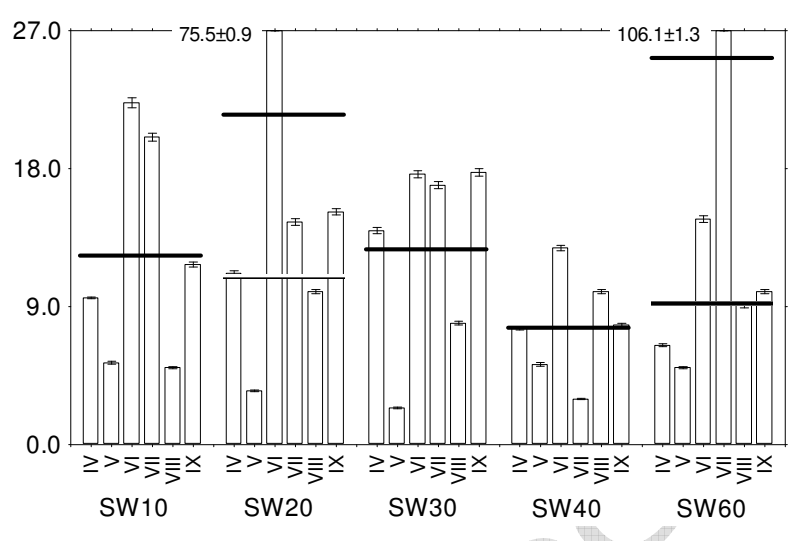

Fe

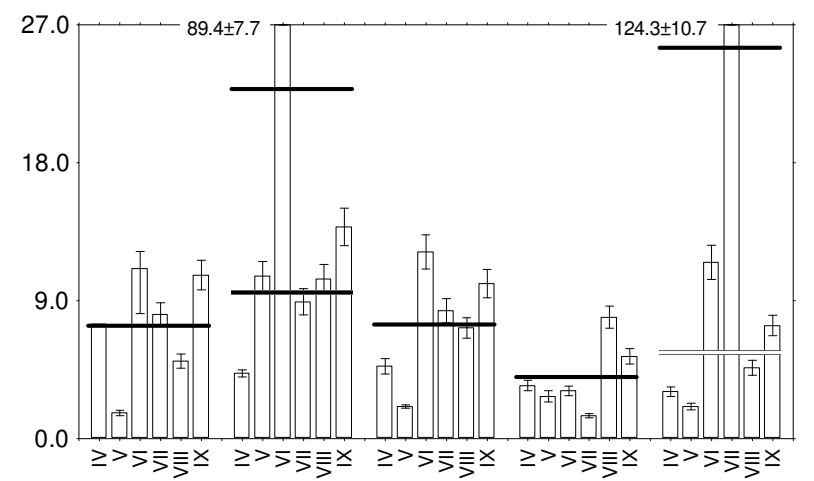

Pb

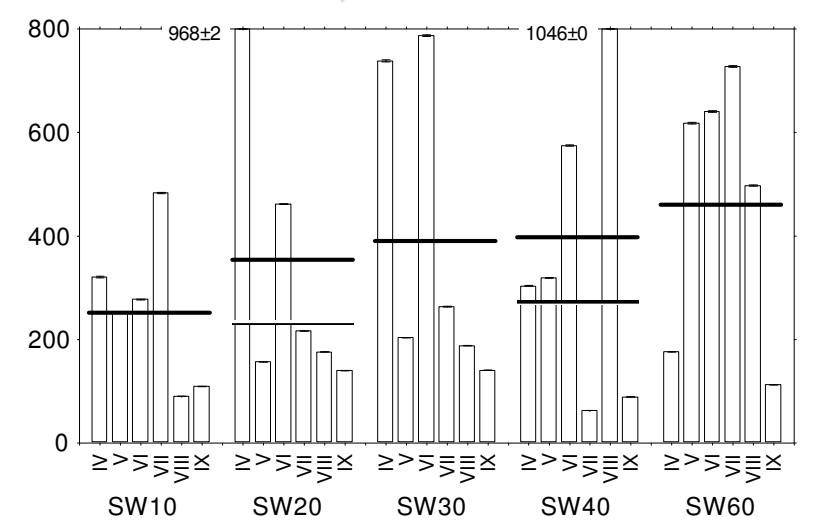

\section{Mn}

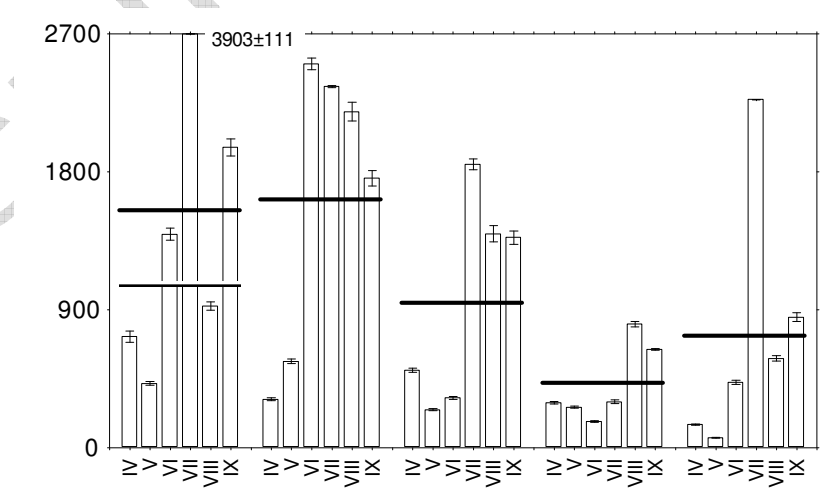

\section{$\mathrm{Zn}$}

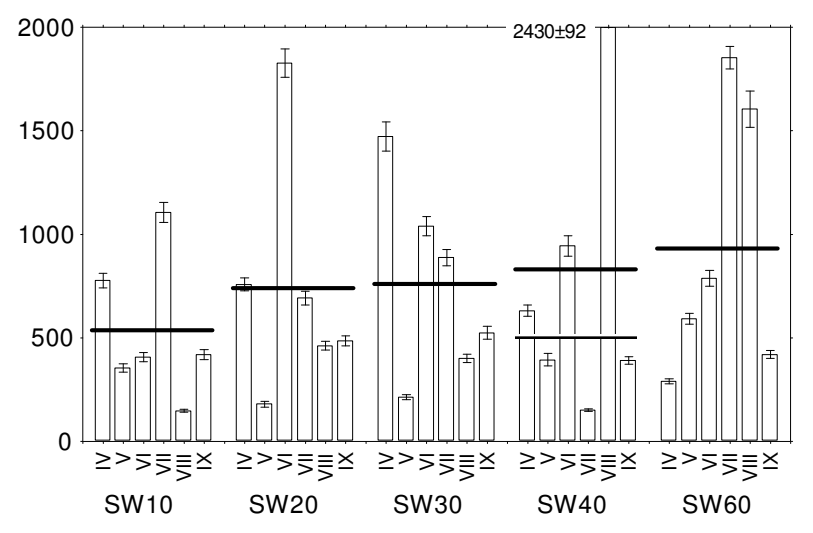

Fig. 3. 
Sokolowski et al. Metal sources to the Baltic clam Macoma balthica in southern Baltic Sea

$\mathrm{Cu}$

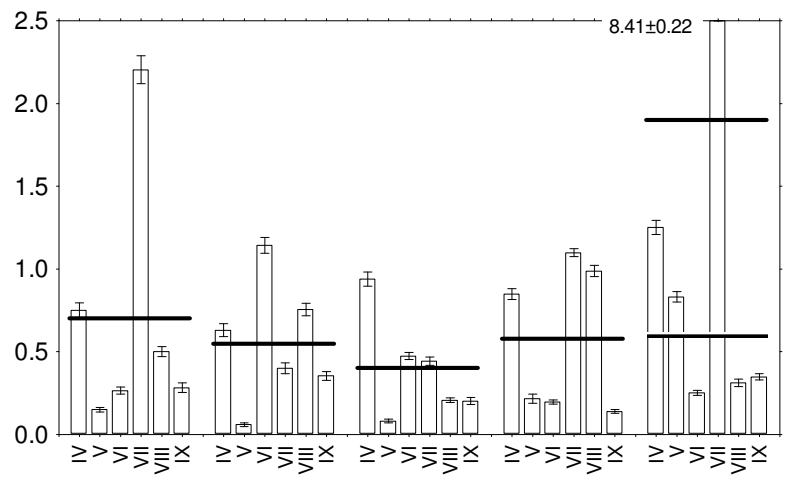

\section{$\mathrm{Ni}$}

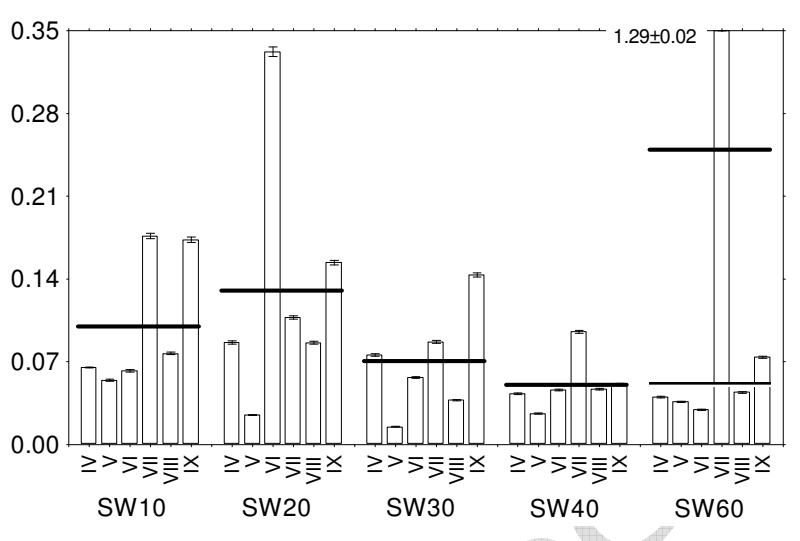

\section{$\mathrm{Fe}$}

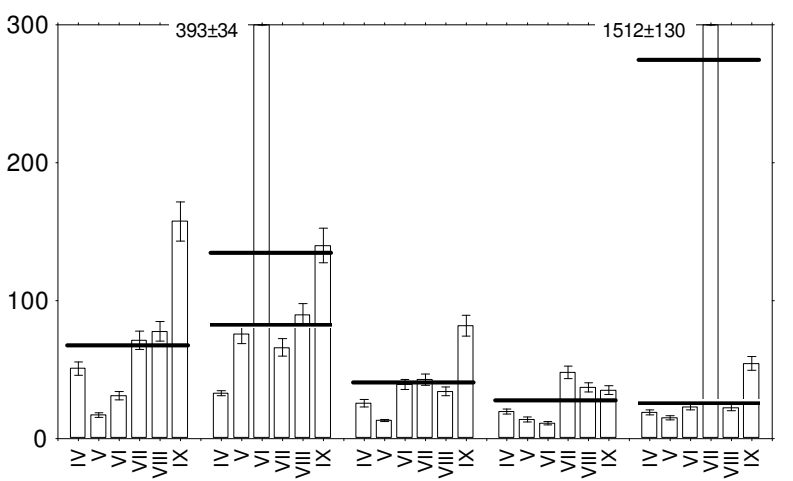

$\mathrm{Pb}$

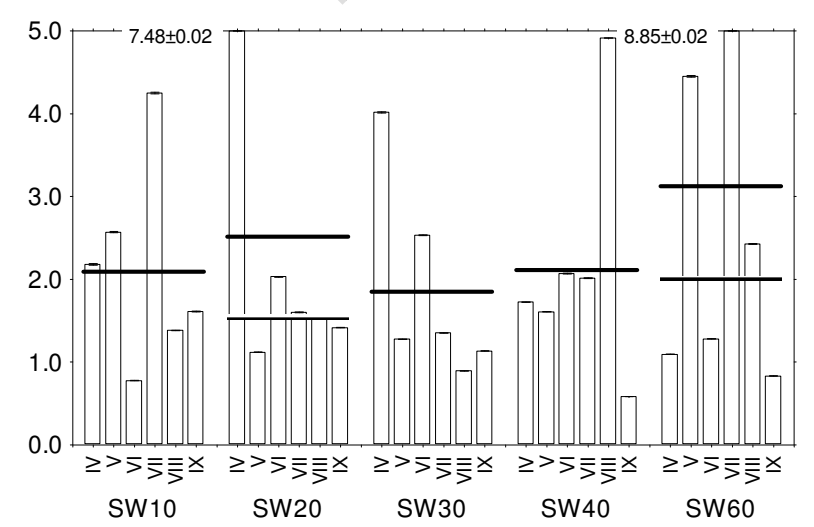

\section{$\mathrm{Mn}$}

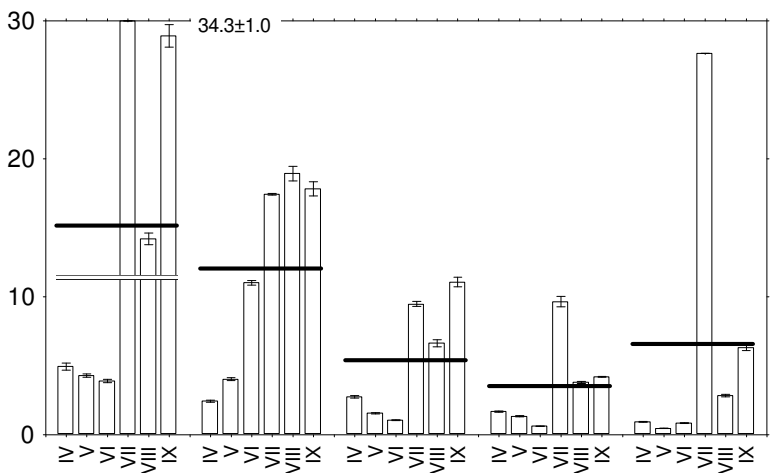

Zn

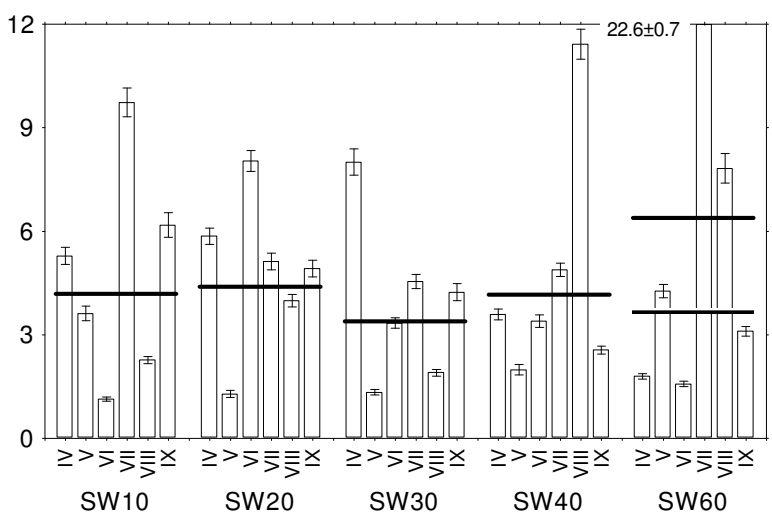

Fig. 4. 
Sokolowski et al. Metal sources to the Baltic clam Macoma balthica in southern Baltic Sea

$\mathrm{Cu}$

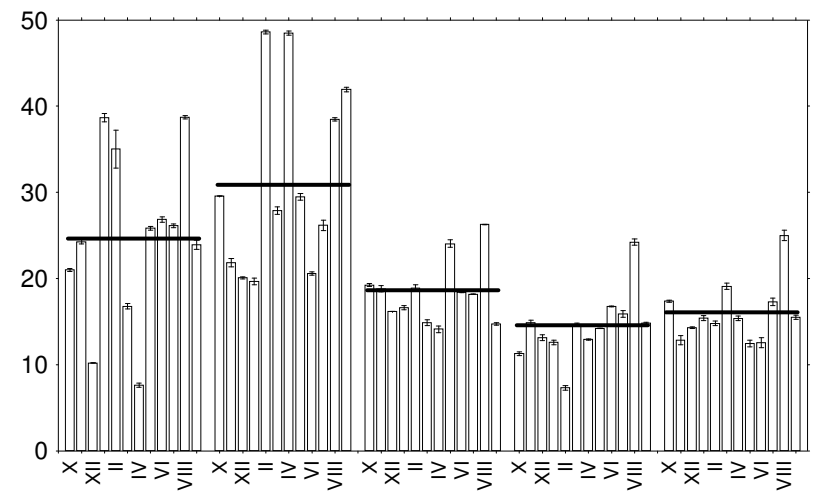

$\mathrm{Ni}$

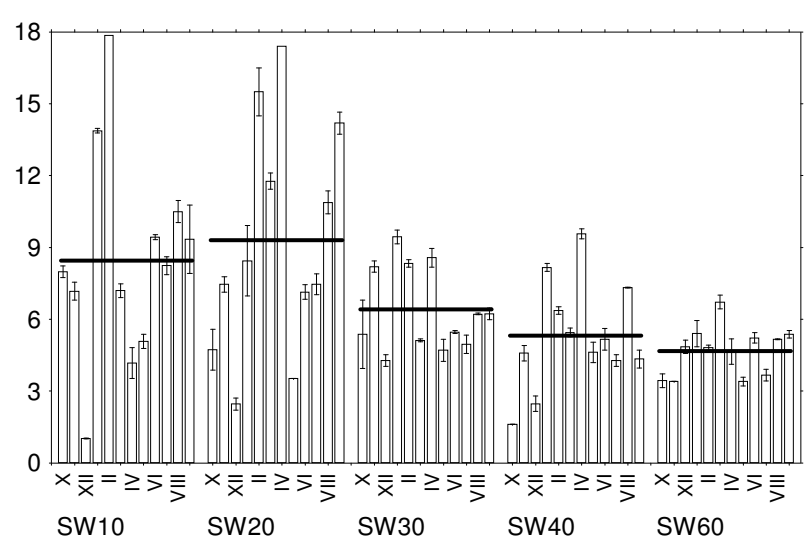

\section{$\mathrm{Fe}$}

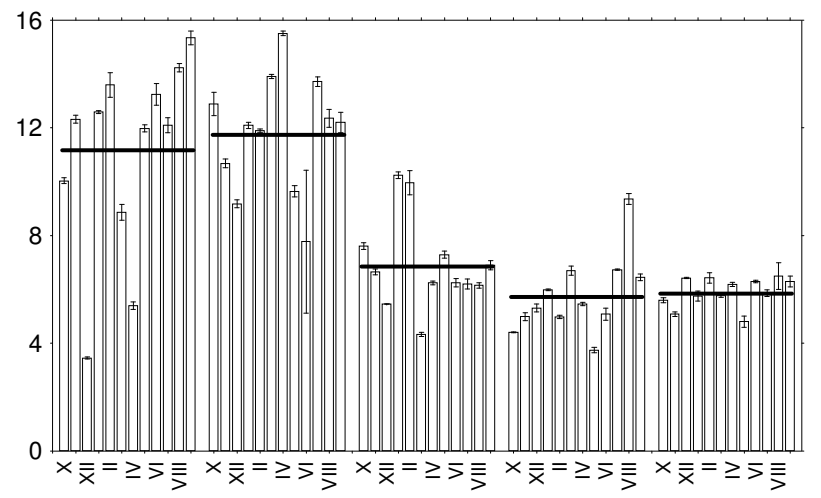

$\mathrm{Pb}$

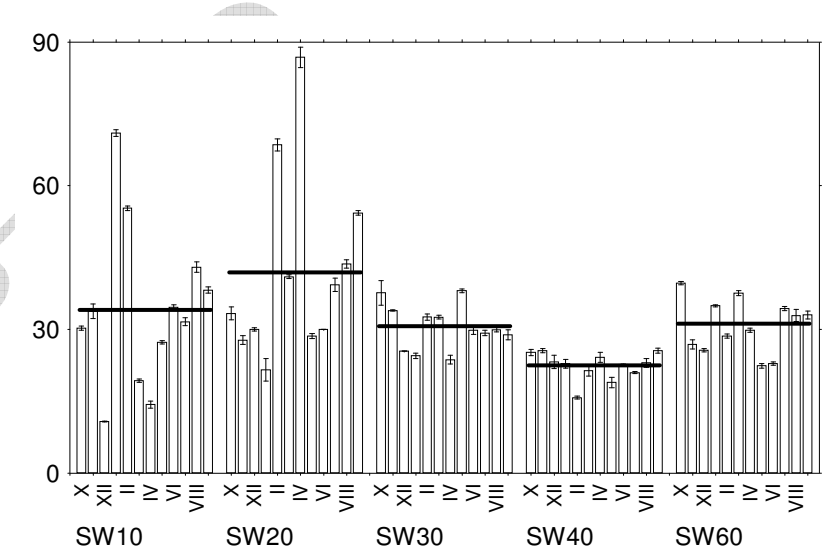

$\mathrm{Mn}$

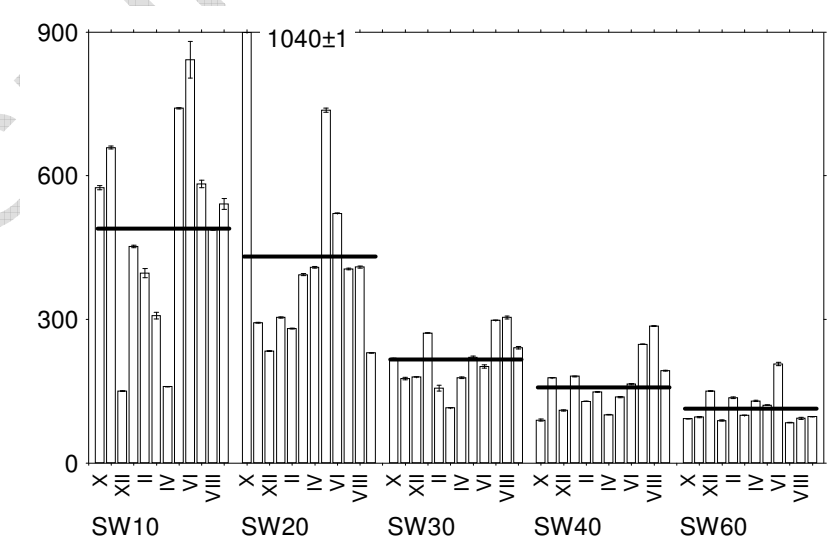

$\mathrm{Zn}$

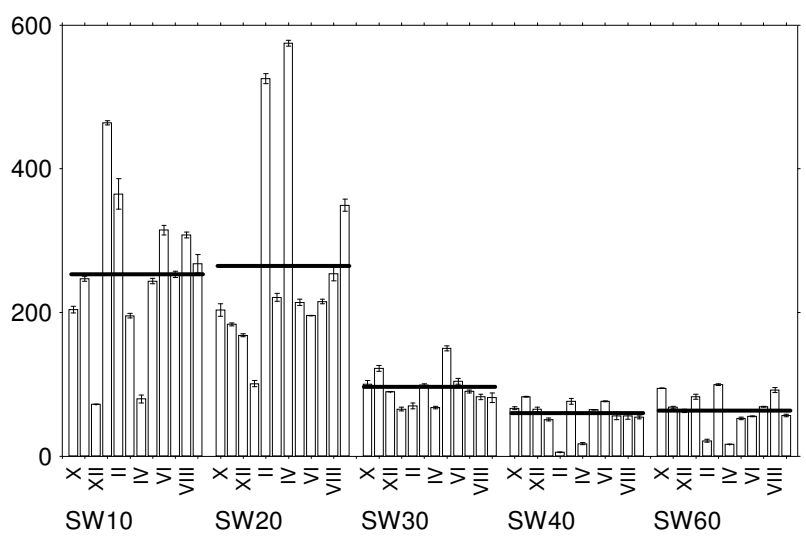

Fig. 5. 
Sokolowski et al. Metal sources to the Baltic clam Macoma balthica in southern Baltic Sea

$\mathrm{Cu}$

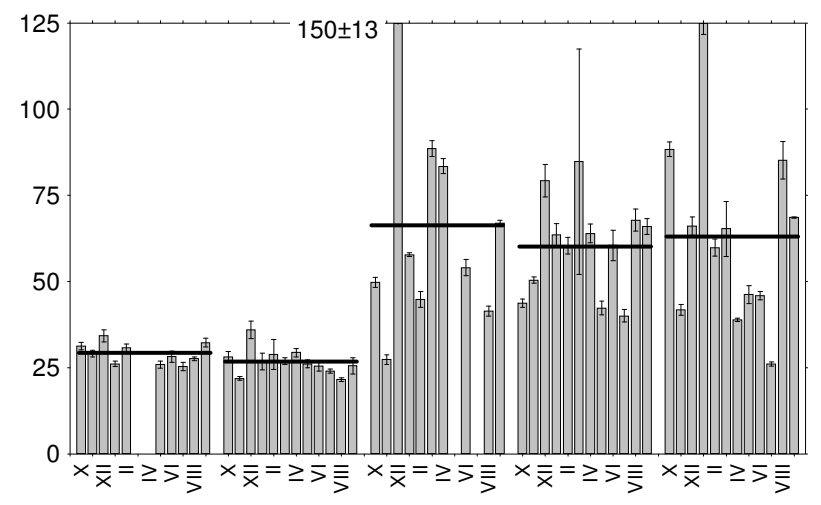

Ni

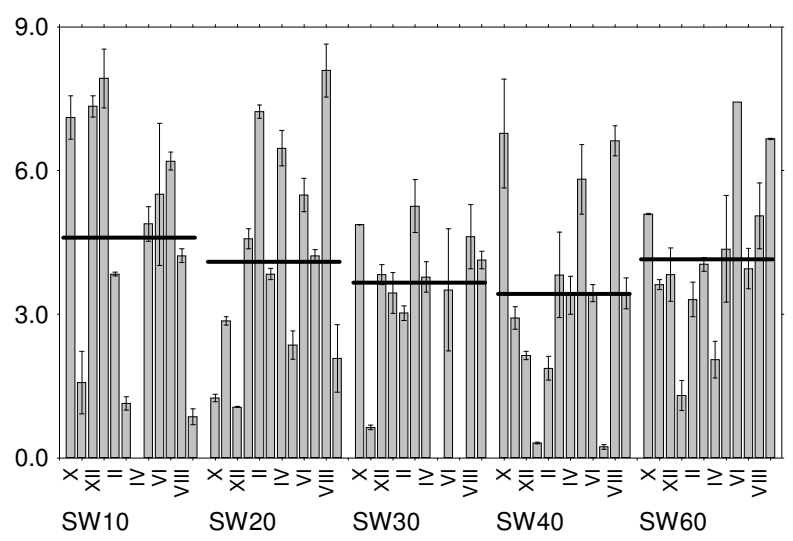

\section{$\mathrm{Fe}$}

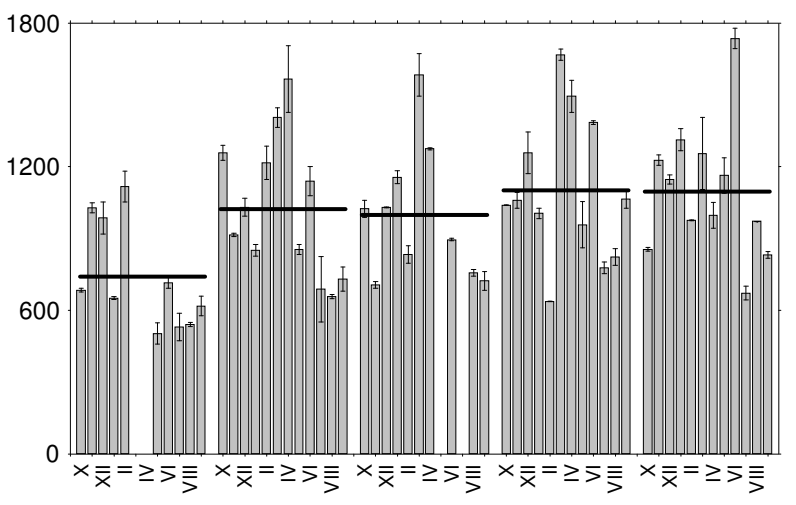

Pb

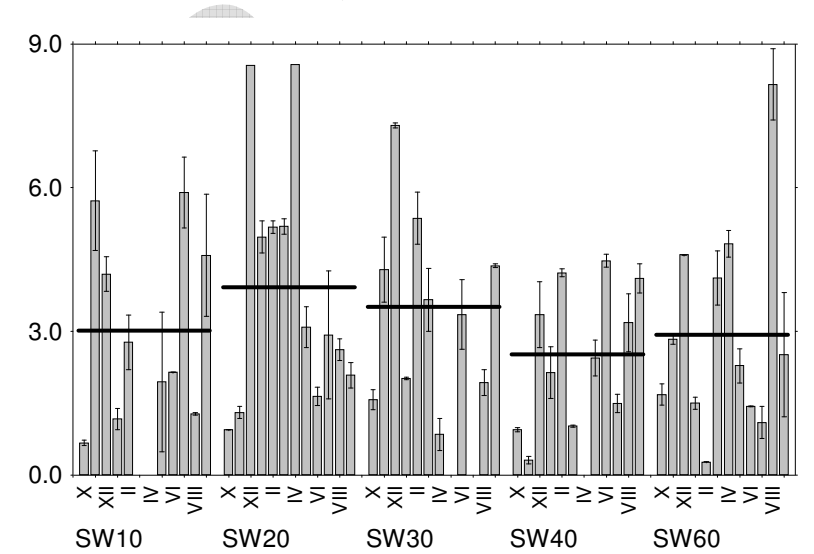

Mn

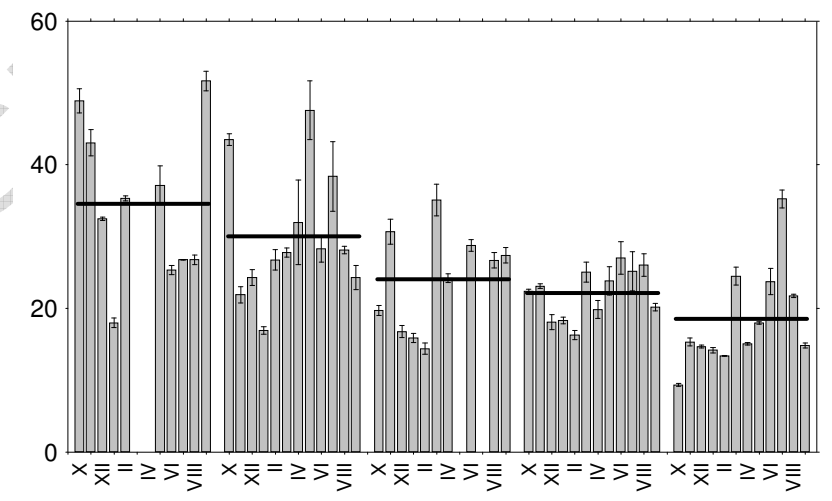

$\mathrm{Zn}$

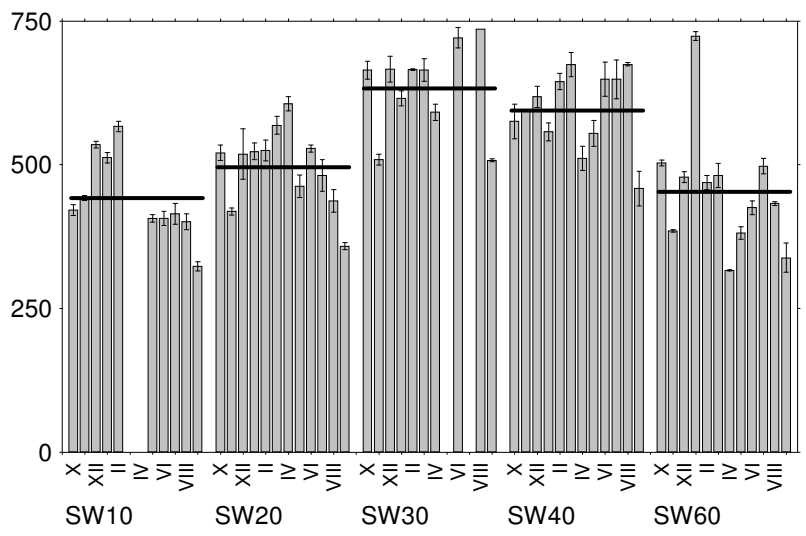

Fig. 6. 